\title{
Fusarium head blight and mycotoxins in wheat: prevention and control strategies across the food chain
}

\author{
A.M. Torres ${ }^{1}$, S.A. Palacios ${ }^{1}$, N. Yerkovich ${ }^{1}$, J.M. Palazzini ${ }^{1}$, P. Battilani ${ }^{2}$, J.F. Leslie ${ }^{3}$, A.F. Logrieco ${ }^{4}$ and S.N. Chulze ${ }^{1}$ \\ ${ }^{1}$ Research Institute on Mycology and Mycotoxicology (IMICO), UNRC-CONICET, Ruta 36, Km 601, Río Cuarto 5800, \\ Córdoba, Argentina; ${ }^{2}$ Institute of Entomology and Plant Pathology, Faculty of Agriculture, Università Cattolica del Sacro \\ Cuore, via Emilia Parmense 84, 29122 Piacenza, Italy; ${ }^{3}$ Department of Plant Pathology, 4024 Throckmorton Plant Sciences \\ Center, Kansas State University, Manhattan, KS 66506-5502, USA; ${ }^{4}$ National Council of Research (CNR), Institute of the \\ Science of Food Production (ISPA), via Amendola 122/O, 70126 Bari, Italy; schulze@exa.unrc.edu.ar
}

Received: 4 February 2019 / Accepted: 3 June 2019

(c) 2019 Wageningen Academic Publishers

OPEN ACCESS (C) (1) (2)

REVIEW ARTICLE

\begin{abstract}
With 744 million metric tons produced in 2017/2018, bread wheat (Triticum aestivum) and durum wheat (Triticum durum) are the second most widely produced cereal on a global basis. Prevention or control of wheat diseases may have an enormous impact on global food security and safety. Fusarium head blight is an economically debilitating disease of wheat that reduces the quantity and quality of grain harvested, and may lead to contamination with the mycotoxin deoxynivalenol, which affects the health of humans and domesticated animals. Current climate change scenarios predict an increase in the number of epidemics caused by this disease. Multiple strategies are available for managing the disease including cultural practices, planting less-susceptible cultivars, crop rotation, and chemical and biological controls. None of these strategies, however, is completely effective by itself, and an integrated approach incorporating multiple controls simultaneously is the only effective strategy to limit the disease and reduce deoxynivalenol contamination in human food and animal feed chains. This review identifies the available tools and strategies for mitigating the damage that can result from Fusarium head blight.
\end{abstract}

Keywords: deoxynivalenol, Fusarium graminearum, disease management strategy, integrated pest management, preharvest, post-harvest, zearalenone

\section{Introduction}

Worldwide production of hexaploid bread wheat (Triticum aestivum) and tetraploid durum wheat (Triticum durum) was estimated at 744 million tons in 2017 (FAO, 2018), making it the second most widely grown cereal after maize and similar in production level to rice. Wheat can be consumed with a minimum of processing and the wide range of wheat cultivars enables the production of different foods to satisfy a myriad of demands. Bread wheat and durum wheat are both important due to their differential adaptation to climatic conditions and environments, and the different food products they are used to produce. Wheat is considered the main food for $35 \%$ of the world's population, providing $20 \%$ of global calories and protein (FAO, 2018). Major wheat exporters include Russia (36 million tons), the European Union (26 million tons), the United States of America (25 million tons), Canada (22.5 million tons), Australia (17.5 million tons), and Argentina (13.7 million tons) (USDA-FAS, 2018).

Increases in global population combined with the impacts of climate change and plant diseases, suggest that wheat production will not meet global demand if the current genetic gain in yield of $\sim 1 \%$ per year remains unchanged. Demand is expected to increase by $70 \%$ by 2050 , and average yields need to increase by at least $1.7 \%$ per year to reach this goal (FAO, 2009). Successful scenarios all give increased disease control a central role in the production of more high-quality grain (Ray et al., 2013). A major disease problem in wheat production is Fusarium head blight (FHB), which causes billions of dollars of losses 
worldwide (McMullen et al., 2012; Windels 2000). The major fungal pathogens associated with FHB include strains from the Fusarium graminearum species complex (FGSC) and related species such as Fusarium avenaceum, Fusarium culmorum and Fusarium poae (Leslie and Summerell, 2006). Other species, e.g. Fusarium acuminatum, Fusarium chlamydosporum, Fusarium equiseti, Fusarium langsethiae, Fusarium sporotrichiodes, Fusarium cerealis and Fusarium tricinctum, are of lesser importance in the global incidence of this disease (Bottalico and Perrone, 2002; Van der Lee et al., 2015). FHB can cause direct losses through decreased grain yield, lower by-product quality, and reduced seed germination, kernel weight, number of kernels per head, and grain marketability (Dahl and Wilson, 2018; Wilson et al., 2018). Harvested grain also may be contaminated with zearalenone (ZEA) and trichothecenes, such as nivalenol (NIV), deoxynivalenol (DON), and DON's acetyl derivatives 3-acetyl-deoxynivalenol (3-ADON) and 15-acetyl-deoxynivalenol (15-ADON) (Desjardins, 2006; McCormick et al., 2013; McMullen et al., 2012). ZEA is a non-steroidal pseudo-oestrogenic mycotoxin (Hidy et al., 1977; JECFA, 2000) and has been associated experimentally with oestrogenic syndromes in pigs and experimental animals (Zinedine et al., 2007). NIV is more commonly found on rice than it is in wheat (Yang et al., 2018). Commercial antibody kits are generally available for the most common trichothecenes produced by $F$. graminearum (Nguyen et al., 2019).

Trichothecenes cause oxidative stress damage through the generation of free radicals, inhibition of protein synthesis, and interference with intercellular signalling (Rocha et al., 2005). Acute DON poisoning causes emesis and diarrhoea in experimental animals while low dose ingestion is associated to anorexia, growth retardation, immunotoxicity and diminish reproduction and development as consequence of maternal toxicity (Pestka, 2010).

Due to the toxic effects of mycotoxins, maximum regulatory limits for DON and ZEA have been established for wheat and wheat by-products (Table 1). These limits are not harmonised across jurisdictions, and are probably exceeded in the diets of some populations even in the first world (Papageorgiou et al., 2018). The need for global harmonisation of mycotoxin regulation is reflected in the recent MycoTox Charter (Logrieco et al., 2018) call to minimise human and animal exposure to mycotoxins worldwide.

Plants can metabolise mycotoxins and the resulting metabolites are commonly termed modified, or 'masked', mycotoxins (Berthiller et al., 2013; Rychlik et al., 2014).

Table 1. Maximum regulatory limits for deoxynivalenol (DON) and zearalenone (ZEA) established for wheat and wheat by-products in different countries/regions.

\begin{tabular}{|c|c|c|c|}
\hline Country / region & Product & DON $(\mu \mathrm{g} / \mathrm{kg})$ & ZEA $(\mu \mathrm{g} / \mathrm{kg})$ \\
\hline \multirow[t]{6}{*}{ Europe $^{1}$} & unprocessed durum wheat & 1,750 & 100 \\
\hline & unprocessed cereals other than durum wheat & 1,250 & 100 \\
\hline & cereal for direct human consumption & 750 & 75 \\
\hline & dried pasta & 750 & - \\
\hline & bread, pastries, biscuits, cereal snacks and breakfast cereals & 500 & 50 \\
\hline & processed cereal-based foods and baby foods & 200 & 20 \\
\hline \multirow[t]{3}{*}{ Brazil $^{2}$} & unprocessed cereals & 3,000 & 40 \\
\hline & bread, pastries, biscuits, cereal snacks and breakfast cereals & 750 & 100 \\
\hline & wheat bran & 1000 & 200 \\
\hline \multirow[t]{2}{*}{ Uruguay $^{3}$} & wheat flour, crackers, etc. & 1000 & 100 \\
\hline & processed products & 1000 & - \\
\hline \multirow[t]{2}{*}{$U_{S A}^{4}$} & finished wheat products for human consumption & 1000 & - \\
\hline & grains and grain by-products & 10,000 & - \\
\hline \multirow[t]{2}{*}{ Canada $^{5}$} & un-processed cereals & 2,000 & - \\
\hline & baby foods & 1000 & - \\
\hline China $^{6}$ & grains and processed products & 1000 & 60 \\
\hline \multicolumn{4}{|l|}{${ }^{1}$ EC, 2006, 2007.} \\
\hline \multicolumn{4}{|l|}{${ }^{2}$ ANVISA, 2017.} \\
\hline \multicolumn{4}{|l|}{${ }^{3}$ MSP, 2001.} \\
\hline \multicolumn{4}{|l|}{${ }^{4}$ FDA, 2010} \\
\hline \multicolumn{4}{|c|}{${ }^{5}$ Health Canada, 2018.} \\
\hline \multicolumn{4}{|l|}{${ }^{6} \mathrm{FAO}, 2004}$. \\
\hline
\end{tabular}


Plants can add glucose residues to DON and ZEA via glucosyltransferases to produce deoxynivalenol-3glucoside (DON-3G) and zearalenone-14-glucoside (ZEA-14G), respectively. These glucosides, at present, are not regulated and usually are not detected in standard tests for DON and ZEA. Chemical reactions during food or feed processing or digestion can cleave the glycosidic bond and release the original mycotoxin. Potential risks attributable to these glucosides per se are unknown, but the mycotoxin molecules released during processing and digestion should be as capable of interfering with animal and human metabolism as they were prior to being bound in the glucoside (Berthiller et al., 2016; EFSA CONTAM Panel, 2014).

FHB was first reported in 1884 in England (Parry et al., 1995) and since then episodic outbreaks have occurred in different countries around the world (Alconada Magliano and Chulze, 2013; Bilska et al., 2018; Ji et al., 2014; McMullen et al., 2012; Obanor et al., 2013). Over the last 25 years the epidemics have become more frequent and more severe, and escalated to a significant threat to world food safety and security. Major losses have been reported in the USA, Canada, Europe, China and South America, e.g. Alconada Magliano and Chulze (2013), Cai et al. (2011), Gilbert and Haber (2013), McMullen et al. (2012), Palazzini et al. (2015), Windels (2000) and Zhang et al. (2013).

The objective of this review is to identify and summarise recent advances in strategies for reducing the impact of FHB, and associated mycotoxin accumulation, across the wheat food chain with a focus on pre- and post-harvest control strategies.

\section{Fusarium head blight}

Ascospores and conidia from Fusarium strains associated with Fusarium head blight persist on crop residues for long periods of time, when temperatures are conducive and sufficient moisture is available for the fungus to grow and sporulate. Wheat ears are susceptible to fungal colonisation during anthesis, a time when fungal perithecia often are ejecting ascospores. Infected wheat heads whiten prematurely and appear discoloured and wrinkled, which may reduce both yield and grain quality by up to $80 \%$ (McMullen et al., 2012).

\section{Pathogens}

The Fusarium graminearum species complex (FGSC) is comprised of 15 formally described phylogenetic species and one additional species that is informally recognised based on genealogical exclusivity and conidial morphology (Aoki et al., 2012, 2014; O’Donnell et al., 2004; Sarver et al., 2011; Starkey et al., 2007). F. graminearum sensu stricto (Leslie and Summerell, 2006) is the main pathogen isolated from wheat in North and South America, Europe and Africa, and can be found in most wheat fields worldwide (Minaar-Ontong et al., 2017; Van der Lee et al., 2015). Although primarily associated with the diseases it causes on wheat and maize, F. graminearum can colonise at least 25 other native grass species, and interactions with these native species may play a role in determining a strain's metabolic and pathogenic capabilities (Lofgren et al., 2018). Genetically, populations of this pathogen are highly variable (Kelly and Ward, 2018), with as much variation within a small portion of a single field as across much of North America (Zeller et al., 2003, 2004). Fusarium asiaticum is the most important phylogenetic species in China, Japan and Korea and also has been isolated in Uruguay and in United States of America (Gale et al., 2011; Qu et al., 2008; Shin et al., 2018; Umpierrez-Failache et al., 2013; Zhang et al., 2012). Strains of other Fusarium species, including $F$. acuminatum, $F$. avenaceum, $F$. cerealis, $F$. chlamydosporum, F. culmorum, F. equiseti, F. langsethiae, F. poae, F. sporotrichiodes and F. tricinctum also may cause the disease (Bottalico and Perrone, 2002).

Strains within the FGSC usually exhibit one of three primary trichothecene profiles: (1) deoxynivalenol and 3-acetyldeoxynivalenol (3-ADON type); (2) deoxynivalenol and 15-acetyldeoxynivalenol (15-ADON type); or (3) nivalenol and its acetylated derivatives (NIV type). The different toxin types are not uniformly distributed across various wheat-growing regions. In North America, Central Europe, Southern Russia, and South America, the 15-ADON type dominates, and in Northern Europe, China, Australia, New Zealand and Korea the 3-ADON type dominates (Van der Lee et al., 2015; Yli-Mattila et al., 2009). The NIV type has been isolated in China, Japan and other Asian countries and less frequently in Europe, South Africa and the Americas (Gale et al., 2011; Suga et al., 2008; Van der Lee et al., 2015; Zhang et al., 2012). In Canada and the United States, a significant increase in the DON/3-ADON type has been observed in recent years (Gale et al., 2011; Guo et al., 2008, Puri and Zhong, 2010; Ward et al., 2008). A fourth trichothecene toxin type was detected in the United States in 2015 (Varga et al., 2015) and produces NX-2, a trichothecene with a chemical structure similar to 3-ADON. To date, strains producing NX-2 have not been found outside North America (Kelly et al., 2016; Liang et al., 2014). PCR analysis of predicted trichothecene genotype often is used as a proxy for chemical analysis of mycotoxin production. Unfortunately, variation in organisation within the Tri gene cluster and the wide variety of mutants that can influence the trichothecene produced have made developing broadly applicable PCR assays difficult (Villafana et al., 2019).

ZEA production by multiple species occurs worldwide, including Canada, the United States, Europe, China, and South America (Chełkowski et al., 2012; Ji et al., 2014; 
Schwake-Anduschus et al., 2015; Stanciu et al., 2015; Tittlemier et al., 2013; Tralamazza et al., 2016; Yerkovich et al., 2017). Since toxin types present in populations can change, it is important to continue monitoring strains associated with FHB to understand current mycotoxin contamination potential within the wheat grain chain.

\section{Infection cycle}

Understanding the pathogen's life cycle, the infection process, and the role of environmental conditions in the epidemiology of the disease, is important for effective FHB management and control. Ascospores (sexual spores) and macroconidia (asexual spores) are the most important source of inoculum, although hyphal fragments also can serve as inocula. Ascospores are produced in specialised sexual structures, termed perithecia (Guenther and Trail, 2005; Trail and Common, 2000), that can be found on plant debris and require exposure to light for proper development (Kim et al., 2015; Krause, 1930). F. graminearum can survive for years as a saprotroph growing in the soil and on dead organic matter, e.g. crop residues. Factors, such as temperature, water, light and $\mathrm{O}_{2}$ availability, can alter survival time (Leplat et al., 2012). Weed plants can serve as reservoir of the pathogen, with genetically diverse $F$. graminearum strains isolated from the inflorescences of healthy weed plants belonging to gramineous and nongramineous species growing in or near commercial fields (Mourelos et al., 2014; Postic et al., 2012; Sneideris et al., 2019). High humidity and warm temperatures in the spring favour the development and maturation of perithecia. Ascospores and macroconidia can travel long distances when carried by the wind and also may be dispersed by rain (Keller et al., 2013; Schmale et al., 2006). Once spores land on a suitable host, high humidity is required for spore germination and plant infection (Bushnell et al., 2003). Airborne inoculum levels at and before anthesis are strongly correlated with disease incidence and DON accumulation (Hellin et al., 2018).

Macroconidia of F. graminearum germinate within 6 to 12 $\mathrm{h}$ post-inoculation on the face of the glume, and by 12 to 24 $h$ post-inoculation hyphae are easily seen and often have reached stomata (Pritsch et al., 2000). The development of FHB after fungal infection depends on the growth stage of the plant, the amount of inoculum, and the weather. Longterm exposure to high humidity and temperatures $\geq 25^{\circ} \mathrm{C}$ promote the disease (Parry et al., 1995). Infection initiates during anthesis, when the wheat flower is directly exposed to the environment. Tissue colonisation depends on cultivar resistance, temperature, humidity, fungal aggressiveness and mycotoxin production (Champeil et al., 2004). Under optimal conditions, the first symptoms of FHB appear 2-4 days after inoculation as slightly brown, water-soaked spots in the spikelets. The infection may be limited to the infected spikelet, or spread across the entire spike. The pathogen disperses from spikelet to spikelet through the rachis. As the infection progresses, the spikelets die, dry up and become bleached resulting in shrivelled kernels (Bushnell et al., 2003).

F. graminearum sensu stricto should be considered a hemibiotroph. After it penetrates the wheat ear there are two distinct phases of infection (Brown et al., 2010; Kazan et al., 2012). Initially the fungus develops a biotrophic relationship with the host in which the invaded tissues remain alive and completely functional. As the infection progresses, the pathogen changes to a necrotrophic state in which it invades the host cells leading to necrosis. Spread of the fungus within the plant occurs more readily in the presence of DON, which blocks a jasmonate-related defence reaction (Bonnighausen et al., 2019), and this mycotoxin functions as a virulence factor in wheat (Bai et al., 2002; Jansen et al., 2005). DON biosynthesis is specifically induced in infection structures, but the toxin is not a prerequisite for the development of these structures or for the initial penetration of wheat tissues (Boenisch and Schäfer, 2011). Thus, the current working hypothesis is that DON is important for suppressing plant defences and enabling the pathogen to break through the rachis node.

\section{Crop phenology}

Understanding plant growth and development is an essential component of a wheat management system. The phenological system of Zadoks et al. (1974) is widely used for wheat and other small grains, with each stage of plant growth assigned a number. Stages are illustrative and the small differences between stages are important since plant growth is continuous and does not stop at the admittedly arbitrary borders of the different stages in the system. Stage 0 is associated with germination, including all steps from a dry seed up to the appearance of the coleoptile. Stage 1 begins with seedling growth, includes the unfolding of the leaves, and continues until tillering. Stage 2 is specific for tillering. Stage 3 begins with stem elongation and continues until the flag leaf appears. Stage 4 is specific for the boot process. Stages 5 and 6 are associated with inflorescence emergence and anthesis, respectively. Caryopsis development occurs in three stages: Stage 7 is the milk stage, Stage 8 is dough development, and Stage 9 is grain ripening. Secondary growth stages are identified by a second digit to better define closely related differences. The second digits follow the Feckes' scale for intermediate stages, which enables the identification of specific details as needed (Zadoks et al., 1974). For example, codes for the number of leaves are important for determining when fungicide(s) and herbicide(s) should be applied.

Some canopy and ear traits are associated with higher levels of FHB (Jones et al., 2018). Flag leaf length and the number of tillers were the most significant canopy traits, 
while spikelet density was the most significant ear trait. Unfortunately reducing flag leaf length, the number of tillers per plant or the density of the spikelets will almost certainly reduce yield in addition to reducing FHB severity.

\section{Pre-harvest strategies to reduce Fusarium head blight and toxin accumulation}

Different strategies for reducing the impact of FHB have been proposed including planting more disease-tolerant cultivars, crop rotation, tillage practices, chemical and biological control and forecasting systems (Chulze et al., 2015; Mesterházy et al., 2003; Wegulo et al., 2015). Different stages of the wheat chain and which strategies can be used in each one to reduce DON accumulation (Figure 1). During the FHB disease cycle, debris, fungal spore release, and weather at anthesis are critical variables for controlling the pathogen. The fungi overwinter on stubble and other plant debris, and under favourable conditions plant infection occurs during flowering. In some regions a wheat-maize rotation is practiced which increases the risk of FHB disease and DON accumulation (Vogelgsang et al., 2011). For integrated management of the disease the best chance for success comes from combining two or more strategies (Acs et al., 2018; McMullen et al., 2012; Mesterhazy et al., 2018a,b; Wegulo et al., 2013).

\section{Biological control of Fusarium head blight}

FHB management by antagonist microorganisms is a very promising strategy. Biocontrol agents can be applied to stubble to reduce pathogen survival and to limit growth on residue of the previous crop (Palazzini et al., 2013; Wegulo et al., 2015). Biocontrol agents can interact with the pathogen either directly, e.g. parasitism or antibiosis, or indirectly, e.g. induction of resistance, competition, or plant growth promotion (Legrand et al., 2017). Multiple antagonist microorganisms are available and can control FHB pathogens both in vivo and in vitro (Table 2). Successful antagonism in vitro, however, is not always a good predictor of successful in vivo activity (Whitaker and Bakker, 2019). Combination applications of chemical controls with biological controls may be possible, but the data to date are relatively limited (Palazzini et al., 2018a).

Reduction of disease severity and the level of DON contamination are both important. Greenhouse applications often are more effective than field applications. Experimental conditions vary considerably and direct comparisons of results from different studies usually cannot be made. Effects may be measured in terms of reduction of fungal growth/sporulation, toxin production or disease severity. The potential use of Cryptococcus (Schisler et al., 2011) may encounter regulatory concerns over the ability of some strains of species in this genus to cause human and animal disease. Work on biocontrol of $F$. graminearum with RNAi (Machado et al., 2018; Yu et al., 2018) is still in preliminary stages. Since 2002, a number very different

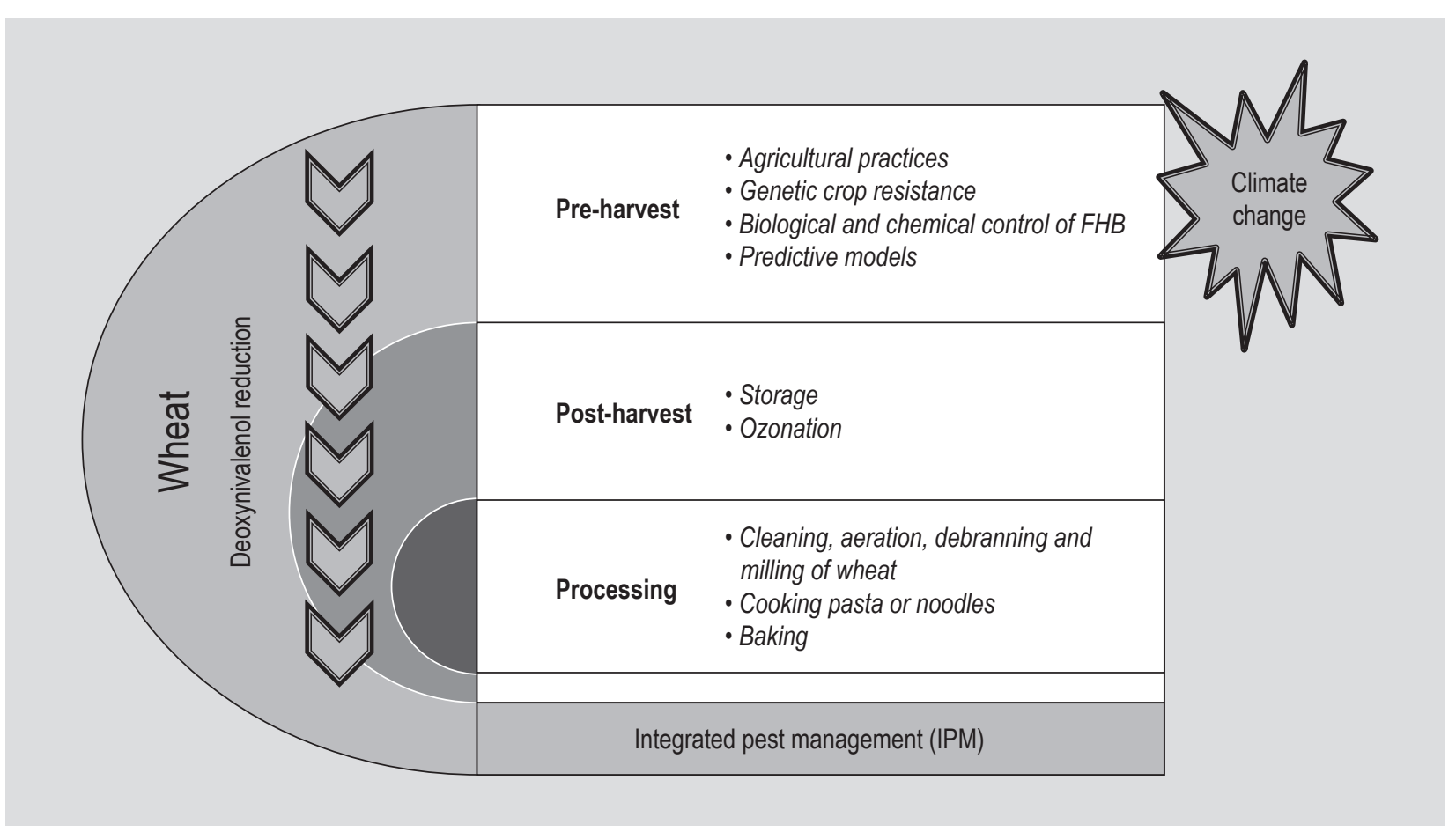

Figure 1. Management to reduce the deoxynivalenol accumulation in wheat. 
Table 2. Biocontrol agents for reducing Fusarium head blight disease and deoxynivalenol (DON) production by Fusarium graminearum.

\begin{tabular}{|c|c|c|c|c|c|c|}
\hline \multirow[t]{2}{*}{ Biocontrol agent } & \multirow{2}{*}{$\begin{array}{l}\text { Experiment } \\
\text { location }\end{array}$} & \multicolumn{4}{|c|}{$\%$ Reduction } & \multirow[t]{2}{*}{ Reference } \\
\hline & & Growth & Sporulation & $\begin{array}{l}\text { Disease } \\
\text { severity }\end{array}$ & DON & \\
\hline Aureobasidium pullulans & greenhouse & - & - & 22 & - & Wachowska and Głowacka, 2014 \\
\hline Bacillus spp. & in vitro & 88 & 96 & -1 & 100 & Zhao et al., 2014 \\
\hline Bacillus velezensis & field & - & - & 25 & 51 & Palazzini et al., 2018b \\
\hline Clonostachys rosea & greenhouse & - & - & 46 & 33 & Xue et al., 2014a,b \\
\hline Cryptococcus aureus + Cryptococcus flavescens & greenhouse & - & - & 32 & - & Schisler et al., 2011 \\
\hline Paecilomyces spp. & in vitro & 62 & - & - & - & El-Hasan et al., 2018 \\
\hline \multirow[t]{2}{*}{ Pseudomonas spp. } & greenhouse & - & - & 25 or 50 & - & Schisler et al., 2006 \\
\hline & field & - & - & 46 or 63 & - & \\
\hline Lysobacter & greenhouse & - & - & 80 & - & Jochum et al., 2006 \\
\hline \multirow[t]{2}{*}{ Streptomyces albidoflavus } & greenhouse & - & - & 40 & $60-100$ & Palazzini et al., 2007 \\
\hline & field & - & - & 30 & 25 & Palazzini et al., 2018b \\
\hline Trichoderma gamsii & in vitro & - & - & - & 90 & Matarese et al., 2012 \\
\hline Trichoderma spp. & in vitro & $72-84$ & - & - & - & El-Hasan et al., 2018 \\
\hline
\end{tabular}

viruses - dsRNA (Chu et al., 2002; Li et al., 2019; Wang et al., 2013; Yu et al., 2009), negative strand RNA (Wang et al., 2018), and positive single-stranded RNA (Chen et al., 2016) viruses - have been described in F. graminearum. In general work with these viruses has not gone very far beyond their description, and infected fungal strains often have few or no morphological differences from the wild type strains ( $\mathrm{Li}$ et al., 2016). Some viruses, however, are reported to cause major changes in internal fungal metabolism (Bormann et al., 2018; Cho et al., 2012; Yu et al., 2016) and/or to reduce pathogenicity (Chu et al., 2002; Darissa et al., 2012; Tóth et al., 2005). These mycoviruses appear to have potential for biocontrol of F. graminearum, but more work appears is needed to develop these viruses as biological control agents.

\section{Chemical control of Fusarium head blight}

Chemical control, i.e. fungicides, is an available strategy to reduce the risk of FHB and can effectively reduce disease severity and mycotoxin contamination in both naturally and artificially infected plants. Fungicide effectiveness depends on other agronomic practices, e.g. crop rotation, tillage, nitrogen fertilisation, seed treatment and resistant cultivars (Acs et al., 2018; Beyer et al., 2006; Edwards, 2004). Many fungicides have been used to reduce FHB, including triazoles, carbendazim, mancozeb, benomyl, prochloraz, propiconazole and triadiamenol. None of these chemicals, however, suffice by themselves to completely control FHB in wheat (Dweba et al., 2017; Spolti et al., 2013; Yuan and Zhou, 2005).
Fungicides, such as tebuconazole, metconazole and prothioconazole (Paul et al., 2008; Pirgozliev et al., 2002) currently provide the most effective control of FHB in wheat, but this control is not complete. Triazole fungicide application, usually tebuconazole or prothioconazole, can reduce FHB incidence, disease severity and DON accumulation. Application is most effective during anthesis, but application after or prior to anthesis also can reduce disease severity and DON accumulation (Paul et al., 2018). Tebuconazole, one of the most widely tested products, reduced FHB severity $25-77 \%$ and DON content $32-89 \%$ in field trials (Haidukowski et al., 2005; Paul et al., 2007). Prothioconazole is the most recently registered broadspectrum fungicide and can reduce FHB disease severity 39$93 \%$ and DON accumulation $40-90 \%$ relative to untreated controls in field trials (Haidukowski et al., 2012; Mesterházy et al., 2003; Müllenborn et al., 2008; Paul et al., 2007, 2008). Triazole-based fungicides inhibit cytochrome P450 sterol $14 \alpha$-demethylase (also termed CYP51 and ERG11), an essential enzyme in fungi that is required for ergosterol biosynthesis. Ergosterol is an indispensable component of fungal cell membranes. Reduction of this enzyme's activity reduces fungal membrane integrity and lowers strain viability (Becher et al., 2011). Different alleles of CYP51 differ in their sensitivity to seven different triazoles (Liu et al., 2011).

Repeated applications of the same fungicide to a field can lead to fungicide resistance in the pathogen population. Thus, the use of mixtures of multiple triazoles and/or 
triazoles with strobilurins are recommended for more sustainable control (Gilbert and Haber, 2013; McMullen et al., 2008; Ramirez et al., 2004). Strobilurins inhibit growth of the fungus by blocking electron transport in the mitochondrial respiratory chain and thereby reduce aerobic respiration and energy production. Low doses of strobilurins or tebuconazole generally are ineffective in controlling $\mathrm{FHB}$, and DON content may even increase relative to an untreated control (Pirgozliev et al., 2002; Ramirez et al., 2004; Simpson et al., 2001).

In China, FHB frequently occurs in the middle and lower reaches of the Yangtze River, the Huaihe River Valley, and the Eastern coastal region. More recently, disease incidence also has increased in the northern and western wheat growing areas. Benzimidazole fungicides, particularly carbendazim (MBC), have been applied regularly to control FHB for over 30 years during wheat heading and flowering in areas with warm and moist weather. The effectiveness of MBC has been threatened by the emergence of resistant pathogen populations in the field. The frequency of $\mathrm{MBC}$-resistant isolates in some regions of China increased gradually, with the efficacy of MBC against F. graminearum decreasing dramatically after 1998 . The decrease in carbendazim efficacy paralleled the increased frequency of resistant strains in the population. A new fungicide, cyanoacrylate, also known as JS399, was developed by the Jiangsu Branch of National Pesticide Research \& Development South Center (NPRDSC) of China. Both MBC-resistant and $\mathrm{MBC}$-sensitive F. graminearum isolates can readily develop resistance to cyanoacrylate. Strains resistant to both fungicides are expected to emerge and potentially create major problems since both fungicides are used extensively in China (Chen and Zhou, 2009).

The selection and timing of fungicide application, the rate of application and the coverage of the spike (Mesterházy et al., 2003, 2011, 2018b) are all variables that can affect the amount of disease controlled. Although excessive fungicide use is regarded as toxic by the general public, mycotoxin contamination usually is more problematic for humans and domesticated animals than is fungicide overapplication. The maximum tolerable Daily Intake (MTDI) for the sum of DON, 3-ADON, 15-ADON and DON-3G in humans is $1 \mu \mathrm{g} / \mathrm{kg}$ body weight/day (EFSA CONTAM Panel, 2017), while the MTDIs for the fungicides range from 18 to 40 $\mu \mathrm{g} / \mathrm{kg}$ body weight/day. Fungicides also degrade under field conditions within two weeks of application, while mycotoxins may persist for years and are stable to heat (Mesterházy et al., 2018a). DON contamination of grain can be reduced with the use of fungicides, but fungicides alone do not suffice to prevent FHB. Other factors that are important for the reduction of disease severity, incidence and DON accumulation include the aggressiveness of the infection in the field, weather, and the implementation of agronomic practices known to mitigate FHB.

\section{Genetic crop resistance}

Resistant cultivars are an important FHB management strategy. At least five types of resistance to FHB are known (Mesterházy, 1995): type I - resistant to pathogen penetration and the onset of disease; type II - resistant to spread of the pathogen in the plant once the disease is established; type III - resistant to infection of the grain; type IV - tolerance of the disease, i.e. infection occurs but grain yield is not reduced; and, type $\mathrm{V}$ - toxin degradation or inhibition of toxin activity. Bread wheat is generally less susceptible to FHB than durum wheat.

Wheat cultivars with different levels and mechanisms of resistance to FHB have been identified (Bai and Shaner, 2004; Bainotti et al., 2017; Wegulo et al., 2013, 2015). Resistance to FHB is quantitative, and is controlled by multiple genes (loci) with individual alleles responsible for small levels of increased resistance. As the different resistance alleles usually must be incorporated individually from exotic backgrounds into commercial breeding lines, developing resistant varieties is a relatively slow process since rare recombination events must be selected to reduce linkage drag (Brar et al., 2019), and high levels of resistance have been difficult to obtain (Bai and Shaner, 2004). Researchers have identified and mapped more than 100 quantitative trait loci (QTLs) that are associated with resistance to FHB (Bai et al., 2018; Buerstmayr et al., 2009; Cainong et al., 2015; Cuthbert et al., 2007; Xue et al., 2010). The pathogen population also contains considerable genetic variation to overcome host resistance (Voss et al., 2010), and managing the disease solely through resistant germplasm seems unlikely in the near future.

Amongst the 100 reported QTLs for FHB resistance, 22 QTL regions on 16 wheat chromosomes have been characterised in more detail. QTLs associated with both reduced FHB severity and lower DON content include: Fhb1 (chromosome 3BS), Qfhs.nau-2DL (2DL), Qfhs.ifa$5 A(5 \mathrm{~A})$, and Fhb7AC (7A) (Buerstmayr and Lemmens, 2015). Fhb1 is derived from the Sumai-3 Chinese wheat cultivar and is, so far, the most important source of FHB resistance. Map-based cloning to identify candidate genes in the Fhb1 region associated a pore-forming toxin-like gene with FHB resistance (Rawat et al., 2016), and suggested a resistance mechanism involving fungal cell wall interactions. This QTL has been incorporated as a resistance source into multiple cultivars and can explain up to $60 \%$ of the phenotypic variation for type II FHB resistance (Buerstmayr et al., 2002). FHB resistant cultivars and breeding lines, including Sumai-3, accumulate very low levels of DON $(<2$ $\mathrm{mg} / \mathrm{kg}$ ) and have fewer than $10 \%$ infected spikelets (Bai et al., 2001). Incorporation of QTLs into commercial lines can be even more difficult as gene pyramiding usually is required for an effective level of resistance to be obtained and both doubled haploids and molecular mapping with 
linked markers may be required to select genetic material with commercial potential (Da Silva et al., 2019).

FHB disease severity was reduced $64-74 \%$ in transgenic wheat expressing a barley UDP-glucosyltransferase (HvUGT13248) (Li et al., 2015b). The transformation of DON to the less toxic DON-3G was $24 \%$ more efficient in the transgenic plants than in the non-transformed controls. Plant height of both transformed and nontransformed plants was similar and taken as evidence that expression of the heterologous enzyme did not alter phenotypic characters. Thus, converting DON to DON3 detoxifies DON in planta and reduces FHB disease severity (Li et al., 2015b). DON-3G is less toxic in planta, but can be hydrolysed to release DON during digestion or food processing. The released DON molecules can be distributed, metabolised and excreted in the same manner as DON molecules that were never incorporated into a DON-3G intermediate. Although toxicity data for DON$3 \mathrm{G}$ is limited and in vivo data on chronic toxicity are not available, the EFSA CONTAM Panel determined that DON$3 \mathrm{G}$ could be associated with acute and chronic adverse health effects similar to those associated with DON (EFSA CONTAM Panel, 2017).

\section{Agricultural practices}

The implementation of good agricultural practices is critical for effective control of FHB. Crop rotation and management of infected residue in the field may reduce FHB severity and DON contamination by up to $30 \%$. F. graminearum can persist as a saprophyte in the field between crops on maize and soybean plant residues. Thus, both crop rotation and tillage can be important in reducing the amount of inoculum (McMullen et al., 2012).

Tillage buries infested plant residues below the soil surface, and prevents the formation of perithecia and ascospores, which require light (Leplat et al., 2012). Reducing the number of ascospores present reduces the inoculum available to infect wheat plants when they are susceptible to infection. Perithecia and ascospores can develop more easily on the above ground residue found in fields managed following no-till practices. While no-till cultivation of wheat has many advantages, FHB can increase in no-till fields (Blandino et al., 2010; Duveiller et al., 2014; Klem et al., 2007; Leplat et al., 2012). Ploughing, when combined with a resistant wheat cultivar and fungicide application reduced DON contamination by $94 \%$ in comparison to direct sowing of a susceptible wheat cultivar and no fungicide application (Blandino et al., 2012).

Good agricultural practices for reducing FHB should include the use of fertilisers and herbicides. FHB severity and/or DON accumulation increase in grain as nitrogen input increases (Heier et al., 2005; Lemmens et al., 2004).
The impact of glyphosate applications on FHB has not been consistent. In minimum-till wheat fields in Canada, the FHB index was higher in fields previously treated with glyphosate (Fernandez et al., 2009a). In another study (Bérubé et al., 2012), glyphosate applied to a soybean crop during the year preceding the wheat crop did not have any effect on the FHB index or DON content. Ryegrass is a widespread weed in wheat-growing regions of Brazil, and glyphosate-resistant ryegrass is common in areas where glyphosate has been applied to agriculturally important crops (Machado et al., 2015). The glyphosate-resistant ryegrass could increase FHB in wheat by serving as a reservoir for increased fungal inoculum during the growing season.

Both chemical and biological seed treatments are available to control seedling blight and to protect wheat seeds and seedlings against seed- or soil-borne pathogens (Dal Bello et al., 2002; Khan et al., 2006; Schaafsma and TamburicIlincic, 2005). The role of these treatments in reducing FHB or DON contamination, which are problems in adult plants, is not clear. F. graminearum inoculum can be found in seeds and soil and the fungus can grow systemically within the plant (Moretti et al., 2014). Treating seeds with commercial fungicides is not sufficient to prevent plant infection, since infection also can occur at other stages of growth (Fernandez et al., 2009b). Although seed treatments may not prevent infection, treatment with chitosan (Bhaskara Reddy et al., 1999) may induce the seedlings to accumulate additional phenolic compounds and lignin that increase their resistance to disease. Planting fungicide-treated seeds improves emergence and tillering, which increases plant canopy density as the crop grows and matures. This increase in canopy density favoured increased FHB, but did not alter the amount of DON accumulated (Schaafsma and Tamburic-Ilinic, 2005). It is possible for $F$. graminearum to colonise parts of the plant other than the heads and the grain, e.g. leaves and stems (Moretti et al., 2014). These plant parts may be used for animal feed and provide an alternate route for the introduction of DON, ZEA and related toxins into the diets of these animals. Thus, further work to understand where and how F. graminearum colonises these portions of the plants is warranted, with the role of seed treatments in reducing or delaying such colonisation of particular interest.

\section{Predictive models}

Forecasting systems (DeWolf and Paul, 2014; Prandini et al., 2009) play a key role in the practical management of FHB since they allow near-real time estimation of FHB disease risks during the growing season. Models have been developed for Argentina (Moschini and Fortugno, 1996; Moschini et al., 2013), Belgium (Detrixhe et al., 2003), Brazil (Del Ponte et al., 2005), Canada (Hooker et al., 2002), Italy (Rossi et al., 2003, 2012), the Netherlands (Franz et al., 2009) and the United States (DeWolf et al., 2003), with 
some more focused on FHB and FHB severity and others on toxin accumulation. In the United States, farmers can obtain real-time estimates of predicted disease severity on line (http://www.wheatscab.psu.edu/) based on a combination of flowering status, predicted weather and the resistance of the planted variety. Such estimates can be used to help determine whether fungicide applications are warranted, but cannot be used as a sole guide since chemical control is most effective if applied prior to flowering and most models rely on weather at the time of flowering for estimates of disease severity (De Wolf and Paul, 2014; Moschini et al., 2013; Rossi et al., 2012). The models also assume a typical harvest date for a region, although extended delays in harvesting can increase contamination by DON or ZEA 10-25 fold (Edwards and Jennings, 2018).

FHB is well suited for risk assessment modelling because of the severity of the epidemics, the losses that result from mycotoxin contamination, and the relatively short time for pathogen sporulation, inoculum dispersal, and host infection (DeWolf et al., 2003; Shah et al., 2019). Models often focus on weather forecasts and the susceptibility of the planted cultivar. Modelling mycotoxin production is more difficult than is modelling disease incidence and severity since toxin production is affected by additional factors, e.g. variation in the capacity of different strains to produce toxins, competition with other microbes in the plant, and effects of fungicides on toxin biosynthesis (Landschoot et al., 2013; Ramirez et al., 2004; Xu et al., 2007). Most of existing models are empirical in nature, as the fundamental factors connecting disease progression and toxin production to the environment are not well understood. Thus, the models quantify the impact of readily-obtained practical variables on DON accumulation at harvest, most commonly through the use of multiple regression.

Existing forecasting systems are based primarily on weather data, e.g. temperature, rainfall and moisture, and have been developed for application in particular geographic regions, usually where they were developed. In Argentina, the Predictive Index (PI\%) of Moschini and Fortugno (1996) estimates mean head blight incidence from temperature (maximum and minimum daily temperature) and moisture variables beginning eight days before heading and ending when 530 degree days have been accumulated, a period viewed as the susceptible period for infection. Since 20052006 wheat growing season, a system for assessing FHB risk has been functioning in the Pampas region of Argentina (Moschini et al., 2013). The system incorporates daily meteorological data from 45 weather stations and short range weather forecasts into predictive FHB models to generate comments and maps showing the potential risk of an FHB epidemic (climayagua.inta.gob.ar).

In the United States, the Fusarium Risk Assessment Tool (www.wheatscab.psu.edu/) estimates the risk of an FHB epidemic with more than $10 \%$ field severity with weather variables observed 15 days prior to flowering. The goal of this tool is to help growers in all US states where wheat and barley are grown assess the risk of FHB in their area and then apply the best management practices to suppress the disease. FHB risk maps are posted daily, from the beginning of winter wheat flowering until the end of the flowering period for spring wheat. The models from this web site are correct $70-80 \%$ of the time.

In Canada, models that predict both FHB severity and DON accumulation risks have been developed. FHB risk maps for the provinces of Saskatchewan and Manitoba are available and based on weather data prior to flowering (https://www.gov.mb.ca/agriculture/crops/plant-diseases/ fhb-risk-forecast-wheat.html). Unfortunately, the models and disease descriptors are different in each province. Farmers are encouraged to use these risk maps (www.gov. mb.ca/agriculture/crops/plant-diseases/fhb-risk-forecastwheat.html; http://www.saskwheat.ca/producer-info/ fusarium-risk-assessment-map) as part of an integrated approach to make management decisions about FHB. DONcast $^{\circledR}$ is a commercially available forecasting system that enables farmers to predict DON accumulation in wheat at harvest. This tool was developed in Canada by Weather Innovations Consulting LP (2018) and utilises actual, forecasted and historical weather data together with field-specific agronomic data, such as cultivar, crop rotation and tillage to predict with $80-85 \%$ accuracy whether the DON accumulation at harvest will be above or below $1 \mathrm{mg} / \mathrm{kg}$ (Giroux et al., 2016). This model also has been tested in Uruguay and France, where its accuracy, 60-80\%, is somewhat lower than what it was in Canada (Schaafsma and Hooker, 2005).

In Italy, a mechanistic model that relies on weather data and wheat growth stages is used to predict both FHB risk and DON contamination. The model produces two indices: one for the risk of FHB on wheat and the other for mycotoxin accumulation. Model validations were based on data collected at several locations in northern Italy and gave satisfactory results since the indices calculated with the model coincided with those obtained from the fields (disease symptoms, kernel infection and mycotoxin concentration in the kernel samples) (Rossi et al., 2003). Mechanistic models should work irrespective of the geographic area in which they were developed, while empiric models rely more on local conditions (Camardo Leggieri et al., 2013). Thus, mechanistic models can be core components of a generalised Decision Support System (Rossi et al., 2012).

\section{Climate change and Fusarium head blight}

FHB is a weather-dependent disease, so climate change may alter both when and where the disease occurs. Continued anticipated growth in $\mathrm{CO}_{2}$ emissions are projected to 
increase the mean global surface temperature in 2100 by $3.7-4.8{ }^{\circ} \mathrm{C}$ compared to pre-industrial levels (IPCC, 2013). Consequently, seasonal and regional climates are expected to become more variable and extreme in terms of temperature and precipitation (IPCC, 2007, 2012).

Battilani et al. (2016) and Van der Fels-Klerx et al. (2016) examined predicted changes resulting from increased temperatures of 2 and $5{ }^{\circ} \mathrm{C}$. Earlier flowering of wheat, changes in pest pressure, and susceptibility of wheat grown in broader geographic regions to FHB and DON contamination all could occur. If elevated $\mathrm{CO}_{2}$ levels and drought/flooding weather events also were included, then the impacts could be even more severe.

Increases in $\mathrm{CO}_{2}$ levels alone could change fungal growth and host-pathogen interactions. In general, fungi are tolerant to elevated $\mathrm{CO}_{2}$ stresses, but when this stress is combined with other environmental stresses their tolerance to increased $\mathrm{CO}_{2}$ levels decreases (Magan and Aldred, 2007). Three-way interactions between elevated $\mathrm{CO}_{2}$ (350400 vs $650-1,200 \mathrm{ppm})$, temperature increases $\left(2-5^{\circ} \mathrm{C}\right)$ and drought stress, all altered the growth of $F$. graminearum. Changing $\mathrm{a}_{\mathrm{w}} \times$ temperature altered the ratio of DON, 3-ADON and 15-ADON, produced both in vitro and in grain (Medina et al., 2017).

Better understanding and modelling of the impact of climate change requires additional experimental data. Increasing temperature results in both increased disease incidence and increased DON accumulation, and rank correlations between 'normal' and 'warm' treatments were weak suggesting that selection for lines that respond well to a warmer environment need to be conducted in the warmer environment (Tessmann and Van Sanford (2018). When both the fungus and the wheat plants were exposed to 390 and $780 \mathrm{ppm} \mathrm{CO}_{2}$ (Vary et al., 2015), there was more disease development at the higher $\mathrm{CO}_{2}$ level. The highest FHB disease levels and associated yield losses occurred when elevated $\mathrm{CO}_{2}$-acclimated F. graminearum was inoculated onto elevated $\mathrm{CO}_{2}$-acclimated wheat. Thus, climate change could potentially expand the geographic range over which FHB occurs and increase losses due to greater disease severity and toxin contamination.

\section{Post-harvest storage and decontamination}

\section{Storage}

FHB as a disease is a pre-harvest risk, but fungal spoilage and contamination of grains with mycotoxins, such as DON and ZEA may continue during storage if moisture, temperature and aeration are suitable for fungal growth and toxin production (Magan et al., 2010). Both temperature and water activity $\left(\mathrm{a}_{\mathrm{w}}\right)$ affect the accumulation of DON and ZEA (Garcia-Celá et al., 2018a). Typically, the maximum amount of ZEA, 1,600 $\mu \mathrm{g} / \mathrm{kg}$, is detected at $25^{\circ} \mathrm{C}$ and 0.93 $\mathrm{a}_{\mathrm{w}}$ with production at the same $\mathrm{a}_{\mathrm{w}}$ at $15^{\circ} \mathrm{C}(550 \mu \mathrm{g} / \mathrm{kg})$ only about a third of that at the higher temperature. The maximum amount of DON, $806 \mu \mathrm{g} / \mathrm{kg}$, was detected at $20{ }^{\circ} \mathrm{C}$ and $0.95 \mathrm{a}_{\mathrm{w}}$ with almost the same production (720 $\mu \mathrm{g} / \mathrm{kg})$ at the same $\mathrm{a}_{\mathrm{w}}$ at $15^{\circ} \mathrm{C}$ (Garcia-Celá et al., 2018a).

Adequate storage requires drying the grain to $12-15.5 \%$ moisture content, depending on the storage temperature, and then maintaining the grain under these conditions until used (Bala, 2016). The most important control measures to adopt during storage include: (1) removal of Fusariumdamaged grains during harvest by using combine settings with an appropriate fan speed to exhaust the 'tombstone' kernels; (2) prompt drying of grain to a storable moisture content; and (3) adequate storage that includes moisture control and control of insects and other pests (Magan et al., 2014).

Dry matter loss by grain is used as a proxy for grain quality. Fungal growth can occur at $20-25^{\circ} \mathrm{C}$ and $0.90 \mathrm{a}_{\mathrm{w}}$, i.e. $19-21 \%$ moisture content, in both wheat and barley with dry matter loss of 0.22-0.44\% (Magan et al., 2010). The respiration rate of stored wheat can be used to estimate dry matter loss and ZEA contamination. Dry matter losses of $<1.0 \%$ have a low risk of either ZEA or DON contamination exceeding EU legislative limits (Garcia-Celá et al., 2018b; Mylona et al., 2012).

Managing storage conditions is very important, but fungal growth and mycotoxin production in storage usually originate from infections that initially occur in the field. Thus, the best strategy for reducing Fusarium and mycotoxin contamination in storage is to follow good agricultural practices during pre-harvest crop growth and harvest, and minimise the fungal infection that occurs before the grain is placed in storage.

\section{Ozonation}

Ozone, $\mathrm{O}_{3}$, has been widely used in the food industry as an antimicrobial agent. Ozone gas is a strong oxidising reagent that can oxidise double bonds in organic compounds and inactivate microorganisms by reacting with intracellular enzymes, nuclear material, cell walls and membranes, spore coats, and viral capsids (Khadre et al., 2001). Ozone can be used to decontaminate mycotoxins in cereals (Chen et al., 2014; Qi et al., 2016; Savi et al., 2014), and has several advantages over traditional chemical agents, including: (1) rapid decomposition (half-life of 20-50 $\mathrm{min}$ ) to molecular oxygen; (2) no residue remains after treatment; (3) onsite generation; and (4) no hazardous chemical storage or disposal (Sandhu et al., 2011). Ozone also can be used to decontaminate produce, equipment, food contact surfaces, and processing environment (Khadre et al., 2001). Wheat contaminated with DON can be treated with $\mathrm{O}_{3}$ to reduce 
DON levels (Li et al., 2015a; Sun et al., 2016; Wang et al., 2016).

Ozone may attack DON at the C9-10 double bond leading to its breakdown to simpler acids, aldehydes, ketones and $\mathrm{CO}_{2}$ (Young et al., 2006). Complete degradation of DON can occur with saturated aqueous ozone ( $25 \mathrm{ppm})$, but with dry ozone no reduction in DON was seen in wheat kernels. Thus, moisture is essential for the reaction between DON and ozone to occur. $\mathrm{pH}$ also is an important factor. At $\mathrm{pH}$ 4-6 DON was degraded readily, while at $\mathrm{pH}$ 7-9 there was little or no degradation. Fungal growth, germination and sporulation all can be limited or completely inhibited by ozone, thus preventing additional toxin biosynthesis after treatment (Kottapalli et al., 2005; Savi et al., 2014; Wu et al., 2006). The efficacy of decontamination or growth limitation depends on a myriad of factors including, but not limited to: $\mathrm{O}_{3}$ concentration, exposure time, substrate, moisture content, $\mathrm{pH}$, mode of application (gaseous or aqueous), and the fungal species present and their growth stage(s) (Trombete et al., 2017; Young et al., 2006). In general DON degradation increases with $\mathrm{O}_{3}$ concentration and processing time (Li et al., 2015a). Grain with higher moisture content is easier to decontaminate with ozone than is grain with a low moisture content (Young et al., 2006).

Ozone is GRAS (Generally Recognized as Safe) for the treatment, storage and processing of food and water (FDA, 2001). Moreover, ozone is considered a 'green technology', since its production is environmental friendly and it leaves no residues in the food. Thus, ozonation could have a role as a sanitising agent for organic food production (Trombete et al., 2017). Treatment of wheat grain and flour with $\mathrm{O}_{3}$ may even improve bread or noodle quality (Li et al., 2012, 2015a; Sandhu et al., 2011; Savi et al., 2014). In particular, flour obtained from wheat treated with ozone had higher tenacity and whiteness, which improved the quality of the flour (Wang et al., 2016).

Ozonation also can degrade ZEA in maize and water. Again, toxin degradation increased with $\mathrm{O}_{3}$ concentration and treatment time (Dudziak, 2012; Qi et al., 2016). In wheat bran, over half of the ZEA (52\%) was degraded after a 15-min exposure to ozone, a rate nearly twice that of the degradation of DON (Santos Alexandre et al., 2018). The quality of the wheat bran was not affected by the treatment. In wheat used for malting, up to $49 \%$ of the ZEA present could be degraded following exposure to $20 \mathrm{mg} / \mathrm{l} \mathrm{O}_{3}$ for 40 to $130 \mathrm{~min}$ (Reinholds et al., 2016). More work on ZEA degradation by ozone is needed, but clearly ozonation has the potential to significantly reduce both ZEA and DON in contaminated wheat.

\section{Post-harvest grain processing}

Post-harvest, wheat is subjected to multiple processes including: cleaning, aeration, debranning and milling that can redistribute the mycotoxins present in the grain, with a comprehensive review of the distribution of mycotoxins through the process recently published (Schaarschmidt and Fauhl-Hassek, 2018). Cleaning, sorting and milling of wheat can reduce the mycotoxin content by $57 \%$ in finished flour (Tibola et al., 2016). In the cleaning process, kernels with extensive fungal growth, broken kernels, dust and fine materials are removed. During the debranning process, outer layers of the wheat grains are removed prior to the milling process. Debranning can increase the milling performance of wheat and the degree of refinement of flour and semolina (Cheli et al., 2013). Fermentation of grains as part of the malting process with lactic acid bacteria can reduce contamination with DON by $34 \%$ and ZEA by $23 \%$ as well as increasing germination by $8-9 \%$ (Juodeikiene $e t$ al., 2018).

In the milling process, mycotoxins may be redistributed and concentrated in particular milling fractions. Mycotoxin levels generally are lower in the inner fractions, e.g. flour and semolina, commonly used for human food, and higher in the outer fractions, e.g. bran, flour shorts, screenings and middlings, used for animal feed (Cheli et al., 2013). Outer fractions may, however, be used for some human foods due to nutritional (essential amino acids, vitamins, antioxidants and mineral content) and physiological benefits such as improved large bowel function, slowed digestion, better absorption of carbohydrate and fat, and reduced risks for some diseases, e.g. obesity, cardiovascular diseases, type 2 diabetes, colon diverticulosis and gastro-intestinal cancers (Hemdane et al., 2016).

DON contamination in finished flour is significantly lower than in milled wheat; however, there are no significant differences in DON levels between milled wheat and bran. DON-3G distribution in the different milling fractions is similar to that of DON, but DON-3G levels in bran were higher than those in flour (Kostelanska et al., 2011; Schwake-Anduschus et al., 2015; Zhang and Wang, 2015). The distribution of ZEA and ZEA-glucosides follows that of DON and DON-3G (Edwards et al., 2011; SchwakeAnduschus et al., 2015; Zheng et al., 2014).

Durum wheat has some different processing considerations since most of this wheat goes to pasta and noodles rather than to flour for bread. Relative to the initial intact grain, DON contamination levels in processed clean wheat, peeled wheat and semolina were 30, 66 and 63\%, respectively. DON levels in the by-products increase about 10 -fold for foliage waste and ranged from 2-5 higher than the unprocessed grain for the three successive dehulling steps (Brera et al., 2013). Although the inner structures of a wheat kernel are 
contaminated at lower levels than the outer portions, even the inner structures can be contaminated by trichotheceneproducing Fusarium strains. Thus, none of the structures within the kernel effectively block fungal colonisation. Semolina is an excellent substrate for trichothecene biosynthesis, but the bran contains biochemical inhibitors that can limit mycotoxin synthesis (Pinson-Gadais et al., 2007).

Durum wheat also can be processed by pearling. This process removes the outer layers of wheat kernels by abrasion and increases the yield of semolina. Spaghetti made with semolina from pearled wheat is less brown and brighter in colour, and the texture of the cooked spaghetti is not changed (De Brier et al., 2015; Dexter et al., 1994). Pearling also was more efficient than milling in reducing Fusarium and DON content in the outer layers of the grain, which were the most contaminated. A $10 \%$ reduction in grain tissue through pearling could lead to a $45 \%$ reduction in DON in the final product (Rios et al., 2009).

Food processing procedures, such as bread-making and pasta production, also can affect levels of DON and ZEA. At both pilot and industrial scales, modifying the baking step (time/temperature ranges), even within the acceptable technological range, was crucial for minimising DON in the final product (Bergamini et al., 2010). Bread-making includes both fermentation and baking steps. DON levels can be altered, either reduced or increased, during dough fermentation (Vidal et al., 2014). Fermentations at high temperatures that avoided enzyme use reduced DON levels at the end of the fermentation, while fermentations that include enzymes, especially xylanase and $\alpha$-amylase, could increase DON levels, probably due to enzymatic release of DON bound to polysaccharides (starch and arabinoxylans) and from DON-3G (Vidal et al., 2016a).

Studies of the effects of bread-making on DON-3G content have not been consistent. In one report (Kostelanska et al., 2011), there were no substantial changes in DON-3G levels during the dough preparation process, i.e. kneading, fermentation, and proofing. If bakery improver enzyme mixtures were included, however, an increase of up to $145 \%$ of conjugated DON-3G occurred in the fermented dough (Kostelanska et al., 2011), although there was an overall decrease in DON-3G by the time the baking process was complete. In a second report (Vidal et al., 2014), the DON$3 G$ level increased during both kneading and fermentation, but the DON level decreased. This result could occur if the DON is glycosylated during the process. In a third report (Vidal et al., 2017), the presence of $\alpha$-amylase and xylanase did not affect the DON-3G concentration during fermentation. In a fourth report (Vidal et al., 2016b), the DON-3G level decreased by the end of the fermentation stage regardless of either the fermentation temperature or the addition of exogenous enzymes. Clearly, additional work is needed in this area.

Reports of the effects of baking on DON levels also have been inconsistent. DON-3G levels can be reduced during baking (Simsek et al., 2012). If the initial level of DON is high, then the amount of reduction in DON level also is high (Bergamini et al., 2010). Changes in DON content during baking can be affected by: (1) the scale at which studies are conducted; (2) the size of the baked items; (3) the time of baking; and (4) the addition of exogenous enzymes, e.g. xylanase and $\alpha$-amylase (Vidal et al., 2016c). Thermal degradation products derived from DON-3G have been found in bread (Kostelanska et al., 2011).

Fermentation and baking reduced ZEA levels by $12 \%$ and $80 \%$, respectively. Baking was the most important step in ZEA reduction since this toxin is thermosensitive under the second set of conditions. In pasta production, $10 \%$ of the ZEA present was detected in the water used for boiling. Less mycotoxin reduction occurred in pasta production than in baking, probably due to the lower temperature used in pasta cooking $\left(85-98^{\circ} \mathrm{C}\right)$ relative to the baked products $\left(220^{\circ} \mathrm{C}\right.$ ) (Keller Bol et al., 2016). Bullerman and Bianchini (2007) reported that temperatures greater than $150{ }^{\circ} \mathrm{C}$ are needed for good reduction of ZEA during extrusion processing of food and Ryu et al. (2003) found that the greatest losses occurred above $175^{\circ} \mathrm{C}$.

Relative to semolina, DON was reduced in dry and cooked pasta by 8 and 41\%, respectively (Brera et al., 2013). The larger reduction for cooked pasta was attributed to DON's solubility in water. These results are consistent with previous results (Visconti et al., 2004) in which the highest levels of DON were found in the bran fraction, and DON levels dropped by $23 \%$ in cleaned wheat, $63 \%$ in semolina, $67 \%$ in spaghetti, and $80 \%$ in cooked spaghetti. Decline of DON levels in the spaghetti after cooking was attributed to DON leaching into the cooking water.

DON was stable during the kneading and drying steps in spaghetti production (Vidal et al., 2016c), but was consistently reduced by $>40 \%$ during cooking. The DON that leached into the boiling water was not degraded and the amount of DON that leached into the water depended on the cooking time, with the amount leached increasing as cooking time increased. These results suggest that the exposure to DON in pasta is minimised if the water in which the pasta is cooked is discarded and not retained for use in a soup. DON-3G also is stable throughout the pasta making process and can be leached into the cooking water (Vidal et al., 2016b; Zhang and Wang, 2015; Figure 2). 


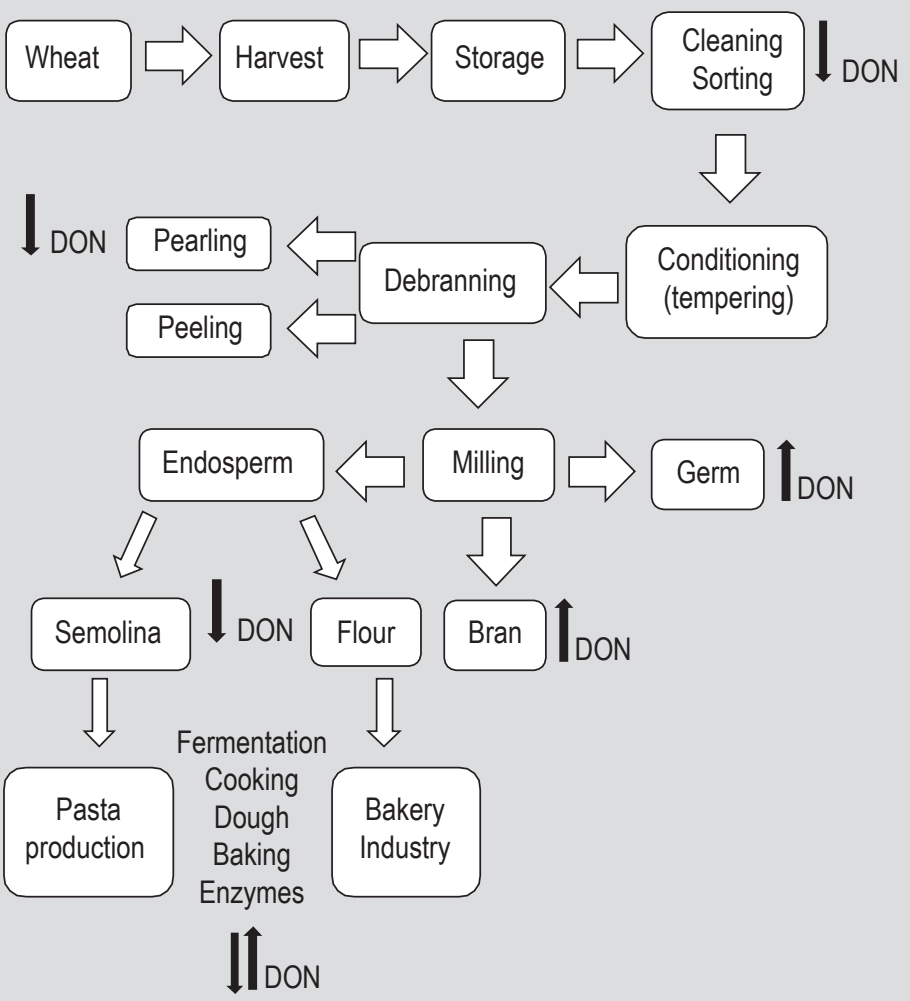

Figure 2. Deoxynivalenol (DON) reduction across the wheat chain.

\section{Conclusions}

Numerous strategies are available to reduce Fusarium head blight and mycotoxin accumulation in the wheat food chain. Among the points to consider are:

- Pre-harvest

- Continued routine monitoring of biodiversity in the pathogen populations is needed to estimate the risks of mycotoxin contamination and of resistance to fungicides.

- Changes in the phenology (e.g. early anthesis) of wheat cultivars under some climate change scenarios could significantly increase FHB and DON accumulation.

- Relative merits of chemical and biological controls should be determined to minimise consumer exposure to fungicides and to ensure an environmentally friendly approach.

- A combination of moderately resistant cultivars with fungicide use as needed is currently the best defence against this disease.

- Forecasting models are important tools to support monitoring and predictions of disease damage and mycotoxin contamination during crop growth and at harvest.

- Survival of pathogen on crop residue should be considered a critical control stage.
- Post-harvest

- Drying, cleaning, segregation and storage of grain under controlled conditions is critical to ensure safety and quality of final products.

- Ozonation is a promising strategy for remediating contaminated materials, but the presence and toxicity of residues from incomplete mycotoxin degradation need further study.

- Processing

- Studies of the effects of glycosylated toxins on human and animal health are needed to determine what role monitoring for the presence of these compounds in grain should play and whether they warrant regulation.

- Further studies of processing are needed to determine the stability, biodegradation and modification of mycotoxins at pilot and industrial scales.

\section{Acknowledgements}

This work was supported in part by H2020-EU3.2-678781MycoKey 'Integrated and Innovative Key Actions for Mycotoxin Management in the Food and Feed Chain' and USDA National Institute of Food and Agriculture Hatch Multi/state project KS1183A. Manuscript no. 19-226-J from Kansas Agricultural experiment Station, Manhattan. 


\section{References}

Acs, K., Lehoczki-Krsjak, S., Varga, M., Kótai, C., Acs, E., Salgo, A. and Mesterházy, Á., 2018. Reduction of deoxynivalenol (DON) contamination by improved fungicide use in wheat. Part 3. Reduction of Fusarium head blight and influence on quality traits in cultivars with different resistance levels. European Journal of Plant Pathology 151: 21-38.

Alconada Magliano, T.M. and Chulze, S.N. (eds.), 2013. Fusarium head blight in Latin America. Springer Netherlands, Dordrecht, the Netherlands.

Agência Nacional de Vigilância Sanitária (ANVISA), 2017. Ministério da Saúde. Resolução da Diretoria Colegiada - RDC No. 138. Brazil. Available at: http://portal.anvisa.gov.br/documents/10181/3219534/ RDC_138_2017_.pdf.

Aoki, T., Ward, T., Kistler, H. and O’Donnell, K., 2012. Systematics, phylogeny and trichothecene mycotoxin potential of Fusarium head blight cereal pathogens. JSM Mycotoxins 62: 91-102.

Aoki, T., O’Donnell, K. and Geiser, D.M., 2014. Systematics of key phytopathogenic Fusarium species: current status and future challenges. Journal of General Plant Pathology 80: 189-201.

Bai, G.H. and Shaner, G., 2004. Management and resistance in wheat and barley to Fusarium head blight. Annual Review of Phytopathology 42: 135-161.

Bai, G.H., Plattner, R.D., Desjardins, A.E. and Kolb, F., 2001. Resistance to Fusarium head blight and deoxynivalenol accumulation in wheat. Plant Breeding 120: 1-6.

Bai, G.H., Desjardins, A.E. and Plattner, R.D., 2002. Deoxynivalenolnonproducing Fusarium graminearum causes initial infection, but does not cause disease spread in wheat spikes. Mycopathologia 153: 91-98

Bai, G.H., Su, Z.Q. and Cai, J., 2018. Wheat resistance to Fusarium head blight. Canadian Journal of Plant Pathology 40: 336-346.

Bainotti, C.T., Lewis, S., Campos, P., Alberione, E., Salines, N., Gomez, D., Fraschina, J., Salines, J., Formica, M.B., Donaire, G., Vanzetti, L.S., Lombardo, L., Nisi, M.M., Cuniberti, M.B., Mir, L., Conde, M.B. and Helguera, M., 2017. MS INTA 416: A new Argentinean wheat cultivar carrying Fhb1 and Lr47 resistance genes. Crop Breeding and Applied Biotechnology 17: 274-280.

Bala, B.K., 2016. Drying and storage of cereal grains, $2^{\text {nd }}$ ed. John Wiley \& Sons, Ames, IA, USA.

Battilani, P., Stroka, J. and Magan, N., 2016. Foreword: mycotoxins in a changing world. World Mycotoxin Journal 9: 647-651.

Becher, R., Weihmann, F., Deising, H.B. and Wirsel, S.G.R., 2011. Development of a novel multiplex DNA microarray for Fusarium graminearum and analysis of azole fungicide responses. BMC Genomics 12: 52.

Bergamini, E., Catellani, D., Dall'asta, C., Galaverna, G., Dossena, A., Marchelli, R. and Suman, M., 2010. Fate of Fusarium mycotoxins in the cereal product supply chain: the deoxynivalenol (DON) case within industrial bread-making technology. Food Additives and Contaminants Part A 27: 677-687.

Berthiller, F., Crews, C., Dall'Asta, C., De Saeger, S., Haesaert, G., Karlovsky, P., Oswald, I.P., Seefelder, W., Speijers, G. and Stroka, J., 2013. Masked mycotoxins: a review. Molecular Nutrition and Food Research 57: 165-186.
Berthiller, F., Maragos, C.M. and Dall'Asta, C., 2016. Introduction to masked mycotoxins. In: Dall'Asta, C. and Berthiller, F. (eds) Masked mycotoxins in food: formation, occurrence and toxicological relevance. The Royal Society of Chemistry, Cambridge, UK, pp. 2-13. Bérubé, M.E., Vanasse, A., Rioux, S., Bourget, N., Dion, Y. and Tremblay, G., 2012. Effect of glyphosate on Fusarium head blight in wheat and barley under different soil tillages. Plant Disease 96: 338-344.

Beyer, M., Klix, M.B., Klink, H. and Verreet, J.-A., 2006. Quantifying the effects of previous crop, tillage, cultivar and triazole fungicides on the deoxynivalenol content of wheat grain - a review. Journal of Plant Diseases and Protection 113: 241-246.

Bhaskara Reddy, M.V., Arul, J., Angers, P. and Couture, L., 1999. Chitosan treatment of wheat seeds induces resistance to Fusarium graminearum and improves seed quality. Journal of Agricultural and Food Chemistry 47: 1208-1216.

Bilska, K., Jurczak, S., Kulik, T., Ropelewska, E., Olszewski, J., Zelechowski, M. and Zapotoczny, P., 2018. Species composition and trichothecene genotype profiling of Fusarium field isolates recovered from wheat in Poland. Toxins 10: 325.

Blandino, M., Pilati, A., Reyneri, A. and Scudellari, D., 2010. Effect of maize crop residue density on Fusarium head blight and on deoxynivalenol contamination of common wheat grains. Cereal Research Communications 38: 550-559.

Blandino, M., Haidukowski, M., Pascale, M., Plizzari, L., Scudellari, D. and Reyneri, A., 2012. Integrated strategies for the control of Fusarium head blight and deoxynivalenol contamination in winter wheat. Field Crops Research 133: 139-149.

Boenisch, M.J. and Schäfer, W., 2011. Fusarium graminearum forms mycotoxin producing infection structures on wheat. BMC Plant Biology 11: 110.

Bonnighausen, J., Schauer, N., Schafer, W. and Bormann, J., 2019. Metabolic profiling of wheat rachis node infection by Fusarium graminearum - decoding deoxynivalenol-dependent susceptibility. New Phytologist 221: 459-469.

Bormann, J., Heinze, C., Blum, C., Mentges, M., Brockmann, A., Landt, S.K., Josephson, B., Indenbirken, D., Spohn, M., Plitzko, B., Loesgen, S., Freitag, M. and Schaefer, W., 2018. Expression of a structural protein of the mycovirus FgV-ch9 negatively affects the transcript level of a novel symptom alleviation factor and causes virus-infection-like symptoms in Fusarium graminearum. Journal of Virology 92: e00326-18.

Bottalico, A. and Perrone, G., 2002. Toxigenic Fusarium species and mycotoxins associated with head blight in small-grain cereals in Europe. European Journal of Plant Pathology 108: 611-624.

Brar, G.S., Pozniak, C.J., Kutcher, H.R. and Hucl, P.J., 2019. Evaluation of Fusarium head blight resistance genes Fhb1, Fhb2, and Fhb5 introgressed into elite Canadian hard red spring wheats: effect on agronomic and end-use quality traits and implications for breeding. Molecular Breeding 39(3): 44.

Brera, C., Peduto, A., Debegnach, F., Pannunzi, E., Prantera, E., Gregori, E., De Giacomo, M. and De Santis, B., 2013. Study of the influence of the milling process on the distribution of deoxynivalenol content from the caryopsis to cooked pasta. Food Control 32: 309-312. 
Brown, N.A., Urban, M., Van de Meene, A.M.L. and HammondKosack, K.E., 2010. The infection biology of Fusarium graminearum: defining the pathways of spikelet to spikelet colonisation in wheat ears. Fungal Biology 114: 555-571.

Buerstmayr, H., Lemmens, M., Hartl, L., Doldi, L., Steiner, B., Grausgruber, H. and Ruckenbauer, P., 2002. Molecular mapping of QTLs for Fusarium head blight resistance in spring wheat. I. Resistance to fungal spread (Type II resistance). Theoretical and Applied Genetics 104: 84-91.

Buerstmayr, H., Ban, T. and Anderson, J.A., 2009. QTL mapping and marker-assisted selection for Fusarium head blight resistance in wheat: a review. Plant Breeding 128: 1-26.

Buerstmayr, H. and Lemmens, M., 2015. Breeding healthy cereals: genetic improvement of Fusarium resistance and consequences for mycotoxins. World Mycotoxin Journal 8: 591-602.

Bullerman, L.B. and Bianchini, A., 2007. Stability of mycotoxins during food processing. International Journal of Food Microbiology 119: 140-146.

Bushnell, W., Hazen, B. and Pritsch, C., 2003. Histology and physiology of Fusarium head blight. In: Leonard, K. and Bushnell, W. (eds.) Fusarium head blight of wheat and barley. American Phytopathological Society, St Paul, MN, USA, pp. 44-83.

Cai, L., Giraud, T., Zhang, N., Begerow, D., Cai, G. and Shivas, R.G., 2011. The evolution of species concepts and species recognition criteria in plant pathogenic fungi. Fungal Diversity 50: 121-133.

Cainong, J.C., Bockus, W.W., Feng, Y., Chen, P., Qi, L., Sehgal, S.K., Danilova, T.V., Koo, D.-H., Friebe, B. and Gill, B.S., 2015. Chromosome engineering, mapping, and transferring of resistance to Fusarium head blight disease from Elymus tsukushiensis into wheat. Theoretical and Applied Genetics 128: 1019-1027.

Camardo-Leggieri, M., Van der Fels-Klerx, H.J. and Battilani, P., 2013. Cross-validation of predictive models for the occurrence of deoxynivalenol in wheat at harvest. World Mycotoxin Journal 6: 389-397.

Champeil, A., Doré, T. and Fourbet, J., 2004. Fusarium head blight: epidemiological origin of the effects of cultural practices on head blight attacks and the production of mycotoxins by Fusarium in wheat grains. Plant Science 166: 1389-1415.

Cheli, F., Pinotti, L., Rossi, L. and Orto, V.D., 2013. Effect of milling procedures on mycotoxin distribution in wheat fractions: A review. LWT - Food Science and Technology 54: 307-314.

Chełkowski, J., Gromadzka, K., Stępień, Ł., Lenc, L., Kostecki, M. and Berthiller, F., 2012. Fusarium species, zearalenone and deoxynivalenol content in preharvest scabby wheat heads from Poland. World Mycotoxin Journal 5: 133-141.

Chen, Y. and Zhou, M.G., 2009. Characterization of Fusarium graminearum isolates resistant to both carbendazim and a new fungicide JS399-19. Phytopathology 99: 441-446.

Chen, R., Ma, F., Li, P.-W., Zhang, W., Ding, X.-X., Zhang, Q., Li, M., Wang, Y.-R. and Xu, B.-C., 2014. Effect of ozone on aflatoxin detoxification and nutritional quality of peanuts. Food Chemistry 146: 284-288.

Chen, X., He, H., Yang, X., Zeng, H., Qiu, D. and Guo, L., 2016. The complete genome sequence of a novel Fusarium graminearum RNA virus in a new proposed family within the order Tymovirales. Archives of Virology 161: 2899-2903.
Cho, W.K., Yu, J., Lee, K.-M., Son, M., Min, K., Lee, Y.-W. and Kim, K.H., 2012. Genome-wide expression profiling shows transcriptional reprogramming in Fusarium graminearum by Fusarium graminearum virus 1-DK21 infection. BMC Genomics 13: 173.

Chu, Y.M., Jeon, J.J., Yea, S.J., Kim, Y.H., Yun, S.H., Lee, Y.-W. and Kim, K.H., 2002. Double-stranded RNA mycovirus from Fusarium graminearum. Applied and Environmental Microbiology 68: 25292534.

Chulze, S.N., Palazzini, J.M., Torres, A.M., Barros, G., Ponsone, M.L., Geisen, R., Schmidt-Heydt, M., and Köhl, J., 2015. Biological control as a strategy to reduce the impact of mycotoxins in peanuts, grapes and cereals in Argentina. Food Additives and Contaminants Part A 32: 471-479.

Cuthbert, P.A., Somers, D.J. and Brulé-Babel, A., 2007. Mapping of Fhb2 on chromosome 6BS: a gene controlling Fusarium head blight field resistance in bread wheat (Triticum aestivum L.). Theoretical and Applied Genetics 114: 429-437.

Dahl, B. and Wilson, W.W., 2018. Risk premiums due to Fusarium Head blight (FHB) in wheat and barley. Agricultural Systems 162: 145-153.

Dal Bello, G.M., Monaco, C.I. and Simon, M.R., 2002. Biological control of seedling blight of wheat caused by Fusarium graminearum with beneficial rhizosphere microorganisms. World Journal of Microbiology and Biotechnology 18: 627-636.

Darissa, O., Adam, G. and Schaefer, W., 2012. A dsRNA mycovirus causes hypovirulence of Fusarium graminearum to wheat and maize. European Journal of Plant Pathology 134: 181-189.

Da Silva, C.L., Fritz, A., Clinesmith, M., Poland, J., Dowell, F. and Peiris, K., 2019. QTL mapping of Fusarium head blight resistance and deoxynivalenol accumulation in the Kansas wheat variety 'Everest'. Molecular Breeding 39(3): 35.

De Brier, N., Gomand, S.V., Joye, I.J., Pareyt, B., Courtin, C.M. and Delcour, J.A., 2015. The impact of pearling as a treatment prior to wheat roller milling on the texture and structure of bran-rich breakfast flakes. LWT - Food Science and Technology 62: 668-674.

Del Ponte, E.M., Fernandes, J.M.C. and Pavan, W., 2005. A risk infection simulation model for Fusarium head blight of wheat. Fitopatologia Brasileira 30: 634-642.

Desjardins, A.E., 2006. Fusarium mycotoxins: chemistry, genetics and biology. American Phytopathological Society Press, St. Paul, MN, USA.

Detrixhe, P., Chandelier, A., Cavelier, M., Buffet, D. and Oger, R., 2003. Development of an agro-meteorological model integrating leaf wetness duration estimation to assess the risk of head blight infection in wheat. Aspects of Applied Biology 68: 199-204.

De Wolf, E. and Paul, P.A., 2014. Predicting mycotoxin contamination in wheat. In: Leslie, J.F. and Logrieco, A.F. (eds.) Mycotoxin reduction in grain chains. John Wiley \& Sons, Ames, IA, USA, pp. 248-257.

De Wolf, E.D., Madden, L.V. and Lipps, P.E., 2003. Risk assessment models for wheat Fusarium head blight epidemics based on withinseason weather data. Phytopathology 93: 428-435.

Dexter, J.E., Martin, D.G., Sadaranganey, G.T., Michaelides, J., Mathieson, N., Tkac, J.J. and Marchylo, B.A., 1994. Preprocessing: effects on durum wheat milling and spaghetti-making quality. Cereal Chemistry 71: 10-16. 
Dudziak, M., 2012. Removal of zearalenone from water by means of ozonation and integrated system of ozonation/nanofiltration. Ecological Chemistry and Engineering A 19: 779-785.

Duveiller, E., Mezzalama, M. and Legrève, A., 2014. Good management practices for minimizing the risk of Fusarium head blight and mycotoxin contamination in nontraditional warmer wheat-growing areas. In: Leslie, J.F. and Logrieco, A.F. (eds.) Mycotoxin reduction in grain chains. John Wiley \& Sons, Ames, IA, USA, pp. 220-231.

Dweba, C.C., Figlan, S., Shimelis, H.A., Motaung, T.E., Sydenham, S., Mwadzingeni, L. and Tsilo, T.J., 2017. Fusarium head blight of wheat: pathogenesis and control strategies. Crop Protection 91: 114-122.

European Commission (EC), 2006. Commission Recommendation (2006/576/EC) of 17 August 2006 on the presence of deoxynivalenol, zearalenone, ochratoxin A, T-2, HT-2 and fumonisins in products intended for animal feeding. Journal of the European Union $\mathrm{L}$ 229: 7-9.

European Commission (EC), 2007. Commission Regulation (2007/1126/EC) of 28 September 2007 amending regulation (EC) No. 1881/2006 setting maximum levels for certain contaminants in foodstuffs as regards Fusarium toxins in maize and maize products. Journal of the European Union L 255: 14.

Edwards, S.G., 2004. Influence of agricultural practices on Fusarium infection of cereals and subsequent contamination of grain by trichothecene mycotoxins. Toxicology Letters 153: 29-35.

Edwards, S.G. and Jennings, P., 2018. Impact of agronomic factors on Fusarium mycotoxins in harvested wheat. Food Additives and Contaminants Part A 35: 2443-2454.

Edwards, S.G., Dickin, E.T., MacDonald, S., Buttler, D., Hazel, C.M., Patel, S. and Scudamore, K.A., 2011. Distribution of Fusarium mycotoxins in UK wheat mill fractions. Food Additives and Contaminants Part A 28: 1694-1704.

European Food Safety Authority Panel on Contaminants in the Food Chain (EFSA CONTAM Panel), 2014. Scientific opinion on the risks for human and animal health related to the presence of modified forms of certain mycotoxins in food and feed. EFSA Journal 12: 3916.

European Food Safety Authority Panel on Contaminants in the Food Chain (EFSA CONTAM Panel), 2017. Scientific opinion on the risks to human and animal health related to the presence of deoxynivalenol and its acetylated and modified forms in food and feed. EFSA Journal 15: 4718. DOI: https://doi.org/10.2903/j. efsa.2017.4718

El-Hasan, A., Schone, J., Hoglinger, B., Walker, F. and Voegele, R.T., 2018. Assessment of the antifungal activity of selected biocontrol agents and their secondary metabolites against Fusarium graminearum. European Journal of Plant Pathology 150: 91-103.

Food and Agriculture Organization of the United Nations (FAO), 2004. Worldwide regulations for mycotoxins in food and feed in 2003. FAO Food and Nutrition Paper 81, FAO, Rome, Italy.

Food and Agriculture Organization of the United Nations (FAO), 2009. How to feed the world in 2050. Proceedings of the expert meeting on how to feed the world in 2050. June 24-26, 2009. FAO, Rome, Italy. Available at: https://tinyurl.com/5ranufw

Food and Agriculture Organization of the United Nations (FAO), 2018. Global information and early warning system. Crop prospects and food situation. FAO, Rome, Italy.
Food and Drug Administration (FDA), 2001. Secondary direct food additives permitted in food for human consumption. Federal Register 66: 33829-33830.

Food and Drug Administration (FDA), 2010. Guidance for industry and FDA: advisory levels for deoxynivalenol (DON) in finished wheat products for human consumption and grains and grain by-products used for animal feed. Available at: https://tinyurl.com/yyldgncj

Fernandez, M.R., Zentner, R.P., Basnyat, P., Gehl, D., Selles, F. and Huber, D., 2009a. Glyphosate associations with cereal diseases caused by Fusarium spp. in the Canadian prairies. European Journal of Agronomy 31: 133-143.

Fernandez, M.R., Turkington, T.K. and May, W.E., 2009b. Effectiveness of fungicide seed treatments for preventing seed-to-seedling transmission of Fusarium graminearum under controlledenvironment conditions. Canadian Journal of Plant Science 89: 811-821.

Franz, E., Booij, K. and Van der Fels-Klerx, I., 2009. Prediction of deoxynivalenol in Dutch winter wheat. Journal of Food Protection 72: 2170-2177.

Gale, L.R., Harrison, S.A., Ward, T.J., O’Donnell, K., Milus, E.A., Gale, S.W. and Kistler, H.C., 2011. Nivalenol-type populations of Fusarium graminearum and F. asiaticum are prevalent on wheat in southern Louisiana. Phytopathology 101: 124-134.

Garcia-Celá, E., Kiaitsi, E., Medina, A., Sulyok, M., Krska, R. and Magan, N., 2018a. Interacting environmental stress factors affect targeted metabolomic profiles in stored natural wheat and that inoculated with F. graminearum. Toxins 10: 56.

Garcia-Celá, E., Kiaitsi, E., Sulyok, M., Medina, A. and Magan, N., 2018b. Fusarium graminearum in stored wheat: use of $\mathrm{CO}_{2}$ production to quantify dry matter losses and relate this to relative risks of zearalenone contamination under interacting environmental conditions. Toxins 10: 86.

Gilbert, J. and Haber, S., 2013. Overview of some recent research developments in Fusarium head blight of wheat. Canadian Journal of Plant Pathology 35: 149-174.

Giroux, M.-E., Bourgeois, G., Dion, Y., Rioux, S., Pageau, D., Zoghlami, S., Parent, C., Vachon, E. and Vanasse, A., 2016. Evaluation of forecasting models for Fusarium head blight of wheat under growing conditions of Quebec, Canada. Plant Disease 100: 1192-1201.

Guenther, J.C. and Trail, F., 2005. The development and differentiation of Gibberella zeae (anamorph : Fusarium graminearum) during colonization of wheat. Mycologia 97: 229-237.

Guo, X.W., Fernando, W.G.D. and Seow-Brock, H.Y., 2008. Population structure, chemotype diversity, and potential chemotype shifting of Fusarium graminearum in wheat fields of Manitoba. Plant Disease 92: 756-762.

Haidukowski, M., Pascale, M., Perrone, G., Pancaldi, D., Campagna, C. and Visconti, A., 2005. Effect of fungicides on Fusarium head blight, yield and deoxynivalenol accumulation in wheat inoculated under field conditions with Fusarium graminearum and Fusarium culmorum. Journal of the Science of Food and Agriculture 85: 191-198. 
Haidukowski, M., Visconti, A., Perrone, G., Vanadia, S., Pancaldi, D., Covarelli, L., Balestrazzi, R. and Pascale, M., 2012. Effect of prothioconazole-based fungicides on Fusarium head blight, grain yield and deoxynivalenol accumulation in wheat under field conditions. Phytopathologia Mediterranea 51: 236-246.

Health Canada, 2018. Health Canada's maximum levels for chemical contaminants in foods. Available at: https://tinyurl.com/yyancm9s

Heier, T., Jain, S.K., Kogel, K.-H. and Pons-Kühnemann, J., 2005. Influence of $\mathrm{N}$-fertilization and fungicide strategies on Fusarium head blight severity and mycotoxin content in winter wheat. Journal of Phytopathology 153: 551-557.

Hellin, P., Duvivier, M., Dedeurwaerder, G., Bataille, C., De Proft, M. and Legreve, A. 2018. Evaluation of the temporal distribution of Fusarium graminearum inoculum above the wheat canopy and its relationship with Fusarium head blight and DON concentration. European Journal of Plant Pathology 151: 1049-1064.

Hemdane, S., Jacobs, P.J., Dornez, E., Verspreet, J., Delcour, J.A. and Courtin, C.M., 2016. Wheat (Triticum aestivum L.) bran in bread making: a critical review. Comprehensive Reviews in Food Science and Food Safety 15: 28-42.

Hidy, P.H., Baldwin, R.S., Greasham, R.L., Keith, C.L. and McMullen, J.R., 1977. Zearalenone and some derivatives: production and biological activities. Advances in Applied Microbiology 22: 59-82.

Hooker, D.C., Schaasfsma, A.W. and Tamburic-Ilinicic, L., 2002. Use weather variables pre- and post-heading to predict deoxynivalenol content in winter wheat. Plant Disease 86: 611-619.

Intergovernmental Panel on Climate Change (IPCC), 2007. Climate change 2007 synthesis report: contribution of working groups I, II and III to the fourth assessment report of the Intergovernmental Panel on Climate Change. In: Core Writing Team, Pachauri, R.K. and Reisinger, A. (eds.) IPCC, Geneva, Switzerland, 104 pp.

Intergovernmental Panel on Climate Change (IPCC), 2012. Managing the risks of extreme events and disasters to advance climate change adaptation: a special report of working groups I and II of the Intergovernmental Panel on Climate Change. In: Field, C.B., Barros, V., Stocker, T.F., Qin, D., Dokken, D.J., Ebi, K.L., Mastrandrea, M.D., Mach, K.J., Plattner, G.-K., Allen, S.K., Tignor, M. and Midgley, P.M. (eds.) Cambridge University Press, Cambridge, UK.

Intergovernmental Panel on Climate Change (IPCC), 2013. Climate change 2013 - the physical science basis: contribution of working group I to the fifth assessment report of the Intergovernmental Panel on Climate Change. In: Stocker, T.F., Qin, D., Plattner, G.-K., Tignor, M., Allen, S.K., Boschung, J., Nauels, A., Xia, Y., Bex, V. and Midgley, P.M. (eds.) Cambridge University Press, Cambridge, UK.

Jansen, C., Von Wettstein, D., Schäfer, W., Kogel, K.-H., Felk, A. and Maier, F.J., 2005. Infection patterns in barley and wheat spikes inoculated with wild-type and trichodiene synthase gene disrupted Fusarium graminearum. Proceedings of the National Academy of Sciences of the USA 102: 16892-16897.

Joint FAO/WHO Expert Committee on Food Additives (JECFA), 2000. $53^{\text {rd }}$ report. Safety evaluation of certain food additives. WHO Food Additives Series 44. WHO, Geneva, Switzerland.

Ji, F., Xu, J., Liu, X., Yin, X. and Shi, J., 2014. Natural occurrence of deoxynivalenol and zearalenone in wheat from Jiangsu province, China. Food Chemistry 157: 393-397.
Jochum, C.C., Osborne, L.E. and Yuen, G.Y., 2006. Fusarium head blight biological control with Lysobacter enzymogenes strain C3. Biological Control 39: 336-344.

Jones, S., Farooqi, A., Foulkes, J. Sparkes, D.L., Linforth, R. and Ray, R.V., 2018. Canopy and ear traits associated with avoidance of Fusarium head blight in wheat. Frontiers in Plant Science 9: 1021. Juodeikiene, G., Bartkiene, E., Cernauskas, D., Cizeikiene, D., Zadeike, D., Lele, V. and Bartkevics, V., 2018. Antifungal activity of lactic acid bacteria and their application for Fusarium mycotoxin reduction in malting wheat grains. LWT - Food Science and Technology 89: 307-314.

Kazan, K., Gardiner, D.M. and Manners, J.M., 2012. On the trail of a cereal killer: recent advances in Fusarium graminearum pathogenomics and host resistance. Molecular Plant Pathology 13: 399-413.

Keller, M.D., Bergstrom, G.C. and Shields, E.J., 2013. The aerobiology of Fusarium graminearum. Aerobiologia 30: 123-136.

Keller Bol, E., Araujo, L., Veras, F.F. and Welke, J.E., 2016. Estimated exposure to zearalenone, ochratoxin $A$ and aflatoxin $B_{1}$ through the consumption of bakery products and pasta considering effects of food processing. Food and Chemical Toxicology 89: 85-91.

Kelly, A.C. and Ward, T.J., 2018. Population genomics of Fusarium graminearum reveals signatures of divergent evolution within a major cereal pathogen. PLoS ONE 13: e0194616.

Kelly, A., Proctor, R.H., Belzile, F., Chulze, S.N., Clear, R.M., Cowger, C., Elmer, W., Lee, T., Obanor, F., Waalwijk, C. and Ward, T.J., 2016. The geographic distribution and complex evolutionary history of the NX-2 trichothecene chemotype from Fusarium graminearum. Fungal Genetics and Biology 95: 39-48.

Khadre, M.A., Yousef, A.E. and Kim, J.G., 2001. Microbiological aspects of ozone applications in food: a review. Journal of Food Science 66: 1242-1252.

Khan, M.R., Fischer, S., Egan, D. and Doohan, F.M., 2006. Biological control of Fusarium seedling blight disease of wheat and barley. Phytopathology 96: 386-394.

Kim, H., Kim, H.-K., Lee, S. and Yun, S.-H., 2015. The white collar complex is involved in sexual development of Fusarium graminearum. PLoS ONE 10: e0120293.

Klem, K., Vanova, M., Hajslova, J., Lancova, K. and Sehnalova, M., 2007. A neural network model for prediction of deoxynivalenol content in wheat grain based on weather data and preceding crop. Plant, Soil and Environment 53: 421-429.

Kostelanska, M., Dzuman, Z., Malachova, A., Capouchova, I., Prokinova, E., Skerikova, A. and Hajslova, J., 2011. Effects of milling and baking technologies on levels of deoxynivalenol and its masked form deoxynivalenol-3-glucoside. Journal of Agricultural and Food Chemistry 59: 9303-9312.

Kottapalli, B., Wolf-Hall, C.E. and Schwarz, P., 2005. Evaluation of gaseous ozone and hydrogen peroxide treatments for reducing Fusarium survival in malting barley. Journal of Food Protection 68: 1236-1240.

Krause, A.W., 1930. Investigations oh the influence of nutrition, illumination, and temperature on the perithecial production of some Hypocreaceae. Contribution to the cultural technique of some parasitic and saprophytic fungi. Zeitschrift fur Parasitenkunde 2: 419-476. 
Landschoot, S., Waegeman, W., Audenaert, K., Haesaert, G. and De Baets, B., 2013. Ordinal regression models for predicting deoxynivalenol in winter wheat. Plant Pathology 62: 1319-1329.

Legrand, F., Picot, A., Cobo-Díaz, J.F., Chen, W. and Le Floch, G., 2017. Challenges facing the biological control strategies for the management of Fusarium head blight of cereals caused by $F$. graminearum. Biological Control 113: 26-38.

Lemmens, M., Haim, K., Lew, H. and Ruckenbauer, P., 2004. The effect of nitrogen fertilization on Fusarium head blight development and deoxynivalenol contamination in wheat. Journal of Phytopathology 152: 1-8.

Leplat, J., Friberg, H., Abid, M. and Steinberg, C., 2012. Survival of Fusarium graminearum, the causal agent of Fusarium head blight. A review. Agronomy for Sustainable Development 33: 97-111.

Leslie, J.F. and Summerell, B.A., 2006. The Fusarium laboratory manual. Blackwell Publishing, Ames, IA, USA.

Li, M., Zhu, K., Wang, B., Guo, X., Peng, W. and Zhou, H., 2012. Evaluation of the quality characteristics of wheat flour and shelf-life of fresh noodles as affected by ozone treatment. Food Chemistry 135: 2163-2169.

Li, M.M., Guan, E.Q. and Bian, K., 2015a. Effect of ozone treatment on deoxynivalenol and quality evaluation of ozonised wheat. Food Additives and Contaminants Part A 32: 544-553.

Li, X., Shin, S., Heinen, S., Dill-Macky, R., Berthiller, F., Nersesian, N., Clemente, T., McCormick, S., and Muehlbauer, G.J., 2015b. Transgenic wheat expressing a barley UDP-glucosyltransferase detoxifies deoxynivalenol and provides high levels of resistance to Fusarium graminearum. Molecular Plant-Microbe Interactions 28: 1237-1246.

Li, P., Lin, Y., Zhang, H., Wang, S., Qiu, D. and Guo, L., 2016. Molecular characterization of a novel mycovirus of the family Tymoviridae isolated from the plant pathogenic fungus Fusarium graminearum. Virology 489: 86-94.

Li, W., Xia, Y., Zhang, H., Zhang, X. and Chen, H., 2019. A Victorivirus from Fusarium asiiaticum, the pathogen of Fusarium head blight in China. Archives of Virology 164: 313-316.

Liang, J.M., Xayamongkhon, H., Broz, K., Dong, Y., McCormick, S.P., Abramova, S., Ward, T.J., Ma, Z.H. and Kistler, H.C., 2014. Temporal dynamics and population genetic structure of Fusarium graminearum in the upper Midwestern United States. Fungal Genetics and Biology 73: 83-92.

Liu, X., Yu, F., Schnabel, G., Wu, J., Wang, Z. and Ma, Z., 2011. Paralogous cyp 51 genes in Fusarium graminearum mediate differential sensitivity to sterol demethylation inhibitors. Fungal Genetics and Biology 48: 113-123.

Lofgren, L.A., LeBlanc, N.R., Certano, A.K., Nachtigall, J., LaBine, K.M., Riddle, J., Broz, K., Dong, Y.H., Bethan, B., Kafer, C.W. and Kistler, H.C., 2018. Fusarium graminearum: pathogen or endophyte of North American grasses? New Phytologist 217: 1203-1212.

Logrieco, A., Miller, J.D., Eskola, M., Krska, R., Ayalew, A., Bandyopadhyay, R., Battilani, P., Bhatnager, D., Chulze, S., De Saeger, S., Li, P., Perrone, G., Poapolathep, A., Rahayu, E., Shepard, G., Stepman, F., Zhang, H. and Leslie, J.F., 2018. The mycotox charter: increasing awareness of, and concerted action for, minimizing mycotoxin exposure worldwide. Toxins 10: 149.
Machado, F.J., Möller, P.A., Nicolli, C.P., Del Ponte, E.M., 2015. First report of Fusarium graminearum, F. asiaticum, and F. cortaderiae as head blight pathogens of annual ryegrass in Brazil. Plant Disease 99: 1859.

Machado, A.K., Brown, N.A., Urban, M., Kanyuka, K. and HammondKosack, K.E., 2018. RNAi as an emerging approach to control Fusarium head blight disease and mycotoxin contamination in cereals. Pest Management Science 74: 790-799.

Magan, N. and Aldred, D., 2007. Post-harvest control strategies: minimizing mycotoxins in the food chain. International Journal of Food Microbiology 119: 131-139.

Magan, N., Aldred, D., Mylona, K. and Lambert, R.J.W., 2010. Limiting mycotoxins in stored wheat. Food Additives and Contaminants Part A 27: 644-650.

Magan, N., Aldred, D. and Baxter, E.S., 2014. Good postharvest storage practices for wheat grain. In: Leslie, J.F. and Logrieco, A.F. (eds) Mycotoxin reduction in grain chains. John Wiley \& Sons, Chichester, UK, pp. 258-267.

Matarese, F., Sarrocco, S., Gruber, S., Seidl-Seiboth, V. and Vannacci, G., 2012. Biocontrol of Fusarium head blight: interactions between Trichoderma and mycotoxigenic Fusarium. Microbiology 158: 98-106.

McCormick, S.P., Alexander, N.J. and Proctor, R.H., 2013. Trichothecene triangle: toxins, genes, and plant disease. In: Gang, D. (ed.) Phytochemicals, plant growth, and the environment. Springer, New York, NY, USA, pp. 1-17.

McMullen, M., Halley, S., Schatz, B., Meyer, S., Jordahl, J. and Ransom, J., 2008. Integrated strategies for Fusarium head blight management in the United States. Cereal Research Communications 36: 563-568.

McMullen, M., Bergstrom, G., DeWolf, E., Dill-Macky, R., Hershman, D., Shaner, G. and Van Sanford, D., 2012. A unified effort to fight an enemy of wheat and barley: Fusarium head blight. Plant Disease 96: 1712-1728.

Medina, Á., Akbar, A., Baazeem, A., Rodríguez, A. and Magan, N., 2017. Climate change, food security and mycotoxins: do we know enough? Fungal Biology Reviews 31: 143-154.

Mesterházy, Á., 1995. Types and components of resistance to Fusarium head blight of wheat. Plant Breeding 114: 377-386.

Mesterházy, Á., Bartók, T. and Lamper, C., 2003. Influence of wheat cultivar, species of Fusarium, and isolate aggressiveness on the efficacy of fungicides for control of Fusarium head blight. Plant Disease 87: 1107-1115.

Mesterházy, Á., Tóth, B., Varga, M., Bartók, T., Szabó-Hevér, Á., Farády, L. and Lehoczki-Krsjak, S., 2011. Role of fungicides, application of nozzle types, and the resistance level of wheat varieties in the control of Fusarium head blight and deoxynivalenol. Toxins 3: 1453-1483.

Mesterházy, Á., Varga, M., Tóth, B., Kótai, C., Bartók, T., Véha, A. and Lehoczki-Krsjak, S., 2018a. Reduction of deoxynivalenol (DON) contamination by improved fungicide use in wheat. Part 1. Dependence on epidemic severity and resistance level in small plot tests with artificial inoculation. European Journal of Plant Pathology 151: 39-55. 
Mesterházy, Á., Varga, M., Tóth, B., Kótai, C., Bartók, T., Véha, A., Acs, K., Vagvolgyi, C. and Lehoczki-Krsjak, S., 2018b. Reduction of deoxynivalenol (DON) contamination by improved fungicide use in wheat. Part 2. Farm scale tests with different nozzle types and updating the integrated approach. European Journal of Plant Pathology 151: 1-20.

Minaar-Ontong, A., Herselman, L., Kriel, W.-M. and Leslie, J.F., 2017. Morphological characterization and trichothecene genotype analysis of a Fusarium head blight population in South Africa. European Journal of Plant Pathology 148: 261-269.

Moretti, A., Panzarini, G., Somma, S., Campagna, C., Ravaglia, S., Logrieco, A.F. and Solfrizzo, M., 2014. Systemic growth of F. graminearum in wheat plants and related accumulation of deoxynivalenol. Toxins 6: 1308-1324.

Moschini, R.C. and Fortugno, C., 1996. Predicting wheat head blight incidence using models based on meteorological factors in Pergamino, Argentina. European Journal of Plant Pathology 102: 211-218.

Moschini, R.C., Martínez, M.I. and Sepulcri, M.G., 2013. Modeling and forecasting systems for Fusarium head blight and deoxynivalenol content in wheat in Argentina. In: Alconada Magliano, T.M. and Chulze, S.N. (eds.) Fusarium head blight in Latin America. Springer Netherlands, Dordrecht, the Netherlands, pp. 205-227.

Mourelos, C.A., Malbrán, I., Balatti, P.A., Ghiringhelli, P.D. and Lori, G.A., 2014. Gramineous and non-gramineous weed species as alternative hosts of Fusarium graminearum, causal agent of Fusarium head blight of wheat, in Argentina. Crop Protection 65: 100-104.

Ministerio de Salud Pública, Uruguay (MSP), 2001. Decreto No. 533/001. Available at: https://tinyurl.com/yxfybkm4

Müllenborn, C., Steiner, U., Ludwig, M. and Oerke, E.C., 2008. Effect of fungicides on the complex of Fusarium species and saprophytic fungi colonizing wheat kernels. European Journal of Plant Pathology 120: $157-166$

Mylona, K., Sulyok, M. and Magan, N., 2012. Relationship between environmental factors, dry matter loss and mycotoxin levels in stored wheat and maize infected with Fusarium species. Food Additives and Contaminants Part A 29: 1118-1128.

Nguyen, N.T., Varga, E., Maragos, C. Baumgartner, S., Adam, G. and Berthiller, F., 2019. Cross-reactivity of commercial and noncommercial deoxynivalenol antibodies to emerging trichothecenes and common deoxynivalenol antibodies. World Mycotoxin Journal 12: 45-53.

Obanor, F., Neateb, S., Simpfendorferc, S., Sabburga, R., Wilsond, P. and Chakraborty, S., 2013. Fusarium graminearum and Fusarium pseudograminearum caused the 2010 head blight epidemics in Australia. Plant Pathology 62: 79-91.

O’Donnell, K., Ward, T.J., Geiser, D.M., Kistler, H.C. and Aoki, T., 2004. Genealogical concordance between the mating type locus and seven other nuclear genes supports formal recognition of nine phylogenetically distinct species within the Fusarium graminearum clade. Fungal Genetics and Biology 41: 600-623.

Palazzini, J.M., Ramirez, M.L., Torres, A.M. and Chulze, S.N., 2007. Potential biocontrol agents for Fusarium head blight and deoxynivalenol production in wheat. Crop Protection 26: 1702-1710.
Palazzini, J.M., Groenenboom-De Haas, B.H., Torres, A.M., Köhl, J. and Chulze, S.N., 2013. Biocontrol and population dynamics of Fusarium spp. on wheat stubble in Argentina. Plant Pathology 62: 859-866.

Palazzini, J., Fumero, V., Yerkovich, N., Barros, G., Cuniberti, M. and Chulze, S.N. 2015. Correlation between Fusarium graminearum and deoxynivalenol during the 2012/13 wheat Fusarium head blight outbreak in Argentina. Cereal Research Communications 43: 627-637.

Palazzini, J.M., Torres, A.M. and Chulze, S.N., 2018a. Tolerance of triazole-based fungicides by biocontrol agents used to control Fusarium head blight in Argentina. Letters in Applied Microbiology 66: 434-438.

Palazzini, J., Roncallo, P., Cantoro, R., Chiotta, M., Yerkovich, N., Palacios, S., Echenique, V., Torres, A., Ramirez, M., Karlovsky, P. and Chulze, S., 2018b. Biocontrol of Fusarium graminearum sensu stricto, reduction of deoxynivalenol accumulation and phytohormone induction by two selected antagonists. Toxins 10: 88.

Papageorgiou, M., Wells, L., Williams, C., White, K.L.M., De Santis, B., Liu, Y., Debegnach, F., Miano, B., Moretti, G., Greetham, S., Brera, C., Atkin, S.L., Hardie, L.J. and Sathyapalan, T., 2018. Occurrence of deoxynivalenol in an elderly cohort in the UK: a biomonitoring approach. Food Additives and Contaminants Part A 35: 2032-2044.

Parry, D.W., Jenkinson, P. and McLeod, L., 1995. Fusarium ear blight (scab) in small grain cereals - a review. Plant Pathology 44: 207-238.

Paul, P.A., Lipps, P.E., Hershman, D.E., McMullen, M.P., Draper, M.A. and Madden, L.V., 2007. A quantitative review of tebuconazole effect on Fusarium head blight and deoxynivalenol content in wheat. Phytopathology 97: 211-220.

Paul, P.A., Lipps, P.E., Hershman, D.E., McMullen, M.P., Draper, M.A. and Madden, L.V., 2008. Efficacy of triazole-based fungicides for Fusarium head blight and deoxynivalenol control in wheat: a multivariate meta-analysis. Phytopathology 98: 999-1011.

Paul, P.A., Bradley, C.A., Madden, L.V., Dalla Lana, F., Bergstrom, G.C., Dill-Macky, R., Wise, K.A., Esker, P.D., McMullen, M., Grybauskas, A., Kirk, W.W., Milus, E. and Ruden, K., 2018. Effects of pre- and postanthesis applications of demethylation inhibitor fungicides on Fusarium head blight and deoxynivalenol in spring and winter wheat. Plant Disease 102: 2500-2510.

Pestka, J.J., 2010. Deoxynivalenol: mechanisms of action, human exposure, and toxicological relevance. Archives of Toxicology 84: 663-679.

Pinson-Gadais, L., Barreau, C., Chaurand, M., Gregoire, S., Monmarson, M. and Richard-Forget, F., 2007. Distribution of toxigenic Fusarium spp. and mycotoxin production in milling fractions of durum wheat. Food Additives and Contaminants 24: 53-62.

Pirgozliev, S.R., Edwards, S.G., Hare, M.C. and Jenkinson, P., 2002. Effect of dose rate of azoxystrobin and metconazole on the development of Fusarium head blight and the accumulation of deoxynivalenol (DON) in wheat grain. European Journal of Plant Pathology 108: 469-478.

Postic, J., Cosic, J., Jurkovic, D., Vrandecic, K., Saleh, A.A. and Leslie, J.F., 2012. Diversity of Fusarium species isolated from weeds and plant debris in Croatia. Journal of Phytopathology 160: 76-81. 
Prandini, A., Sigolo, S., Filippi, L., Battilani, P. and Piva, G., 2009. Review of predictive models for Fusarium head blight and related mycotoxin contamination in wheat. Food and Chemical Toxicology 47: 927-931.

Pritsch, C., Muehlbauer, G.J., Bushnell, W.R., Somers, D.A. and Vance, C.P., 2000. Fungal development and induction of defense response genes during early infection of wheat spikes by Fusarium graminearum. Molecular Plant-Microbe Interactions 13: 159-169.

Puri, K.D. and Zhong, S., 2010. The 3ADON population of Fusarium graminearum found in North Dakota is more aggressive and produces a higher level of DON than the prevalent 15ADON population in spring wheat. Phytopathology 100: 1007-1014.

Qi, L., Li, Y., Luo, X., Wang, R., Zheng, R., Wang, L., Li, Y., Yang, D., Fang, W. and Chen, Z., 2016. Detoxification of zearalenone and ochratoxin A by ozone and quality evaluation of ozonised corn. Food Additives and Contaminants Part A 33: 1700-1710.

Qu, B., Li, H.P., Zhang, J.B., Xu, Y.B., Huang, T., Wu, A.B., Zhao, C.S., Carter, J., Nicholson, P. and Liao, Y.C., 2008. Geographic distribution and genetic diversity of Fusarium graminearum and F. asiaticum on wheat spikes throughout China. Plant Pathology 57: 15-24.

Ramirez, M.L., Chulze, S.N. and Magan, N., 2004. Impact of environmental factors and fungicides on growth and deoxinivalenol production by Fusarium graminearum isolates from Argentinian wheat. Crop Protection 23: 117-125.

Rawat, N., Pumphrey, M.O., Liu, S., Zhang, X., Tiwari, V.K., Ando, K., Trick, H.N., Bockus, W.W., Akhunov, E., Anderson, J.A. and Gill, B.S., 2016. Wheat $F h b 1$ encodes a chimeric lectin with agglutinin domains and a pore-forming toxin-like domain conferring resistance to Fusarium head blight. Nature Genetics 48: 1576-1580.

Ray, D.K., Mueller, N.D., West, P.C. and Foley, J.A., 2013. Yield trends are insufficient to double global crop production by 2050. PLoS ONE 8: e664288.

Reinholds, G., Juodeikiene, G., Bartkiene, E.D., Zadeike, D., Bartkevics, V., Krungleviciute, V., Cernauskas, D. and Cizeikiene, D., 2016. Evaluation of ozonation as a method for mycotoxin degradation in malting wheat grains. World Mycotoxin Journal 9: 409-417.

Rios, G., Pinson-Gadais, L., Abecassis, J., Zakhia-Rozis, N. and LullienPellerin, V., 2009. Assessment of dehulling efficiency to reduce deoxynivalenol and Fusarium level in durum wheat grains. Journal of Cereal Science 49: 387-392.

Rocha, O., Ansari, K. and Doohan, F.M., 2005. Effects of trichothecene mycotoxins on eukaryotic cells: a review. Food Additives and Contaminants 22: 369-378.

Rossi, V., Giosuè, S., Pattori, E., Spanna, F. and Del Vecchio, A.A., 2003. A model estimating the risk of Fusarium head blight on wheat. EPPO Bulletin 33: 421-425.

Rossi, V., Caffi, T. and Salinari, F., 2012. Helping farmers face the increasing complexity of decision-making for crop protection. Phytopathologia Mediterranea 51: 457-479.

Rychlik, M., Humpf, H.U., Marko, D., Dänicke, S., Mally, A., Berthiller, F., Klaffke, H. and Lorenz, N., 2014. Proposal of a comprehensive definition of modified and other forms of mycotoxins including 'masked' mycotoxins. Mycotoxin Research 30: 197-205.

Ryu, D., Hanna, M.A., Eskridge, K.M. and Bullerman, L.B., 2003. Heat stability of zearalenone in an aqueous buffered model system. Journal of Agricultural and Food Chemistry 51: 1746-1748.
Sandhu, H.P.S., Manthey, F.A. and Simsek, S., 2011. Quality of bread made from ozonated wheat (Triticum aestivum L.) flour. Journal of the Science of Food and Agriculture 91: 1576-1584.

Santos Alexandre, A.P., Vela Paredes, R.S., Silva Santos, A., Silva Costa, N., Guidolin Canniatti-Brazaca, S., Calori Dominguez, M.A. and Augusto, P.E.D., 2018. Ozone treatment to reduce deoxynivalenol (DON) and zearalenone (ZEN) contamination in wheat bran and its impact on nutritional quality. Food Additives and Contaminants Part A 35: 1189-1199.

Sarver, B.A.J., Ward, T.J., Gale, L.R., Broz, K., Kistler, H.C., Aoki, T., Nicholson, P., Carter, J. and O'Donnell, K., 2011. Novel Fusarium head blight pathogens from Nepal and Louisiana revealed by multilocus genealogical concordance. Fungal Genetics and Biology 48: 1096-1107.

Savi, G.D., Piacentini, K.C., Bittencourt, K.O. and Scussel, V.M., 2014. Ozone treatment efficiency on Fusarium graminearum and deoxynivalenol degradation and its effects on whole wheat grains (Triticum aestivum L.) quality and germination. Journal of Stored Products Research 59: 245-253.

Schaafsma, A.W. and Hooker, D.C., 2005. Validation of the Doncast prediction tool in wheat across France and Uruguay. In: Canty, S.M., Boring, T., Wardwell, J., Siler, L. and Ward, R.W. (eds.) Proceedings of the National Fusarium head blight forum. December 11-13, 2005. Milwaukee, WI, USA. Michigan State University, East Lansing, MI, pp. 148.

Schaafsma, A.W. and Tamburic-Ilincic, L., 2005. Effect of seeding rate and seed treatment fungicides on agronomic performance, Fusarium head blight symptoms, and DON accumulation in two winter wheats. Plant Disease 89: 1109-1113.

Schaarschmidt, S. and Fauhl-Hassek, 2018. The fate of mycotoxins during the processing of wheat for human consumption. Comprehensive Reviews in Food Science and Food Safety 17: 556-593.

Schisler, D.A., Khan, N.I., Boehm, M.J., Lipps, P.E., Slininger, P.J. and Zhang, S., 2006. Selection and evaluation of the potential of cholinemetabolizing microbial strains to reduce Fusarium head blight. Biological Control 39: 497-506.

Schisler, D.A., Slininger, P.J., Boehm, M.J. and Paul, P.A., 2011. Coculture of yeast antagonists of Fusarium head blight and their effect on disease development in wheat. Plant Pathology Journal 10: $128-137$

Schmale, D.G., Leslie, J.F., Zeller, K.A., Saleh, A.A., Shields, E.J. and Bergstrom, G.C., 2006. Genetic structure of atmospheric populations of Gibberella zeae. Phytopathology 96: 1021-1026.

Schwake-Anduschus, C., Proske, M., Sciurba, E., Muenzing, K., Koch, M. and Maul, R., 2015. Distribution of deoxynivalenol, zearalenone, and their respective modified analogues in milling fractions of naturally contaminated wheat grains. World Mycotoxin Journal 8: 433443

Shah, D.A., DeWolf, E.D., Paul, P.A. and Madden, L.V., 2019. Functional data analysis of weather variables linked to Fusarium head blight epidemics in the United States. Phytopathology 109: 96-110.

Shin, S., Son, J.H., Park, J.-C., Kim, K.-H., Yoon, Y.-M., Cheong, Y.-K., Kim, K.-H., Hyun, J.-N., Park, C.S., Dill-Macky, R. and Kang, C.-S., 2018. Comparative pathogenicity of Fusarium graminearum isolates from wheat kernels in Korea. Plant Pathology Journal 34: 347-355. 
Simpson, D.R., Weston, G.E., Turner, J.A., Jennings, P. and Nicholson, P., 2001. Differential control of head blight pathogens of wheat by fungicides and consequences for mycotoxin contamination of grain. European Journal of Plant Pathology 107: 421-431.

Simsek, S., Burgess, K., Whitney, K.L., Gu, Y. and Qian, S.Y., 2012. Analysis of deoxynivalenol and deoxynivalenol-3-glucoside in wheat. Food Control 26: 287-292.

Sneideris, D., Ivanauskas, A., Suproniene, S., Kadziene, G. and Sakalauskas, S., 2019. Genetic diversity of Fusarium graminearum isolated from weeds. European Journal of Plant Pathology 153: 639-643.

Spolti, P., Del Ponte, E.M., Dong, Y., Cummings, J.A. and Bergstrom, G.C., 2013. Triazole sensitivity in a contemporary population of Fusarium graminearum from New York wheat and competitiveness of a tebuconazole-resistant isolate. Plant Disease 98: 607-613.

Stanciu, O., Banc, R., Cozma, A., Filip, L., Miere, D., Mañes, J. and Loghin, F., 2015. Occurence of Fusarium mycotoxins in wheat from Europe - a review. Acta Universitatis Cibiniensis Series E: Food Technology 19: 35-60.

Starkey, D.E., Ward, T.J., Aoki, T., Gale, L.R., Kistler, H.C., Geiser, D.M., Suga, H., Tóth, B., Varga, J., and O’Donnell, K., 2007. Global molecular surveillance reveals novel Fusarium head blight species and trichothecene toxin diversity. Fungal Genetics and Biology 44: 1191-1204.

Suga, H., Karugia, G.W., Ward, T., Gale, L.R., Tomimura, K., Nakajima, T., Miyasaka, A., Koizumi, S., Kageyama, K. and Hyakumachi, M., 2008. Molecular characterization of the Fusarium graminearum species complex in Japan. Phytopathology 98: 159-166.

Sun, C., Ji, J., Wu, S., Sun, C., Pi, F., Zhang, Y. and Tang, L., 2016. Saturated aqueous ozone degradation of deoxynivalenol and its application in contaminated grains. Food Control 69: 185-190.

Tessmann, E.W. and Van Sanford, D.A., 2018. GWAS for Fusarium head blight related traits in winter wheat (Triticum aestivum L.) in an artificially warmed treatment. Agronomy 8(5): 68.

Tibola, C.S., Fernandes, J.M.C. and Guarienti, E.M., 2016. Effect of cleaning, sorting and milling processes in wheat mycotoxin content. Food Control 60: 174-179.

Tittlemier, S.A., Roscoe, M., Trelka, R., Gaba, D., Chan, J.M., Patrick, S.K., Sulyok, M., Krska, R., McKendry, T. and Gra, T., 2013. Fusarium damage in small cereal grains from western Canada: 2. Occurrence of Fusarium toxins and their source organisms in durum wheat harvested in 2010. Journal of Agricultural and Food Chemistry 61: 5438-5448.

Tóth, B., Fonad, P., Mesterházy, Á. and Varga, M., 2005. Doublestranded RNA mycoviruses in Fusarium culmorum and Fusarium graminearum. Cereal Research Communications 33: 733-740.

Trail, F. and Common, R., 2000. Perithecial development by Gibberella zeae: a light microscopy study. Mycologia 92: 130-138.

Tralamazza, S.M., Braghini, R. and Corrêa, B., 2016. Trichothecene genotypes of the Fusarium graminearum species complex isolated from Brazilian wheat grains by conventional and quantitative PCR. Frontiers in Microbiology 7: 1-7.

Trombete, F.M., Porto, Y.D., Freitas-Silva, O., Pereira, R.V., Direito, G.M., Saldanha, T. and Fraga, M.E., 2017. Efficacy of ozone treatment on mycotoxins and fungal reduction in artificially contaminated soft wheat grains. Journal of Food Processing and Preservation 41: 12927.
Umpierrez-Failache, M., Garmendia, G., Pereyra, S., RodriguezHaralambides, A., Ward, T.J. and Vero, S., 2013. Regional differences in species composition and toxigenic potential among Fusarium head blight isolates from Uruguay indicate a risk of nivalenol contamination in new wheat production areas. International Journal of Food Microbiology 166: 135-140.

United States Department of Agriculture - Foreign Agricultural Service (USDA-FAS). 2018. Grain: world markets and trade. Available at: https://tinyurl.com/hw6kxft

Van der Fels-Klerx, H.J., Liu, C. and Battilani, P., 2016. Modelling climate change impacts on mycotoxin contamination. World Mycotoxin Journal 9: 717-726.

Van der Lee, T., Zhang, H., Van Diepeningen, A. and Waalwijk, C., 2015. Biogeography of Fusarium graminearum species complex and chemotypes: a review. Food Additives and Contaminants Part A 32: 453-460.

Varga, E., Wiesenberger, G., Hametner, C., Ward, T.J., Dong, Y., Schöfbeck, D., McCormick, S., Broz, K., Stückler, R., Schuhmacher, R., Krska, R., Kistler, H.C., Berthiller, F. and Adams, G., 2015. New tricks of an old enemy: isolates of Fusarium graminearum produce a type A trichothecene mycotoxin. Environmental Microbiology 17: 2588-2600.

Váry, Z., Mullins, E., McElwain, J.C. and Doohan, F.M., 2015. The severity of wheat diseases increases when plants and pathogens are acclimatized to elevated carbon dioxide. Global Change Biology 21: 2661-2669.

Vidal, A., Morales, H., Sanchis, V., Ramos, A.J. and Marín, S., 2014. Stability of DON and OTA during the breadmaking process and determination of process and performance criteria. Food Control 40: 234-242.

Vidal, A., Ambrosio, A., Sanchis, V., Ramos, A.J. and Marín, S., 2016a. Enzyme bread improvers affect the stability of deoxynivalenol and deoxynivalenol-3-glucoside during breadmaking. Food Chemistry 208: 288-296.

Vidal, A., Bendicho, J., Sanchis, V., Ramos, A.J. and Marín, S., 2016b. Stability and kinetics of leaching of deoxynivalenol, deoxynivalenol3-glucoside and ochratoxin A during boiling of wheat spaghettis. Food Research International 85: 182-190.

Vidal, A., Sanchis, V., Ramos, A.J. and Marín, S., 2016c. The fate of deoxynivalenol through wheat processing to food products. Current Opinion in Food Science 11: 34-39.

Vidal, A., Sanchis, V., Ramos, A.J. and Marín, S., 2017. Effect of xylanase and $\alpha$-amylase on DON and its conjugates during the breadmaking process. Food Research International 101: 139-147.

Villafana, R.T., Ramdass, A.C. and Rampersad, S.N., 2019. Selection of Fusarium trichothecene toxin genes for molecular detection depends on TRI gene cluster organization and gene function. Toxins 11: 36 .

Visconti, A., Haidukowski, E.M., Pascale, M. and Silvestri, M., 2004. Reduction of deoxynivalenol during durum wheat processing and spaghetti cooking. Toxicology Letters 153: 181-189.

Vogelgsang, S., Hecker, A., Musa, T., Dorn, B. and Forrer, H.R., 2011. On-farm experiments over 5 years in a grain maize/winter wheat rotation: effect of maize residue treatments on Fusarium graminearum infection and deoxynivalenol contamination in wheat. Mycotoxin Research 27: 81-96. 
Voss, H.-H., Bowden, R.L., Leslie, J.F. and Miedaner, T., 2010. Variation and transgression of aggressiveness among two Gibberella zeae crosses developed from highly aggressive parental isolates. Phytopathology 100: 904-912.

Wachowska, U. and Głowacka, K., 2014. Antagonistic interactions between Aureobasidium pullulans and Fusarium culmorum, a fungal pathogen of winter wheat. BioControl 59: 635-645.

Wang, L., Luo, Y., Luo, X., Wang, R., Li, Y., Li, Y., Shao, H. and Chen, Z., 2016. Effect of deoxynivalenol detoxification by ozone treatment in wheat grains. Food Control 66: 137-144.

Wang, S., Kondo, H., Liu, L., Guo, L. and Qiu, D., 2013. A novel virus in the family Hypoviridae from the plant pathogenic fungus Fusarium graminearum. Virus Research 174: 69-77.

Wang, L., He, H., Wang, S., Chen, X., Qiu, D., Hideki, K. and Guo, L., 2018. Evidence for a novel negative-stranded RNA mycovirus isolated from the plant pathogenic fungus Fusarium graminearum. Virology 518: 232-240.

Ward, T.J., Clear, R.M., Rooney, A.P., O’Donnell, K., Gaba, D., Patrick, S., Starkey, D.E., Gilbert, J., Geiser, D.M. and Nowicki, T.W., 2008. An adaptive evolutionary shift in Fusarium head blight pathogen populations is driving the rapid spread of more toxigenic Fusarium graminearum in North America. Fungal Genetics and Biology 45: 473-484.

Wegulo, S.N., Bockus, W.W., Hernandez-Nopsa, J.F., Peiris, K.H.S. and Dowell, F.E., 2013. Integration of fungicide application and cultivar resistance to manage Fusarium head blight in wheat. In: Nita, M. (ed.) Fungicides - showcases of integrated plant disease management from around the world. InTech, London, UK. DOI: https://doi.org/10.5772/53096

Wegulo, S.N., Baenziger, P.S., Hernandez, J., Bockus, W.W. and HallenAdams, H., 2015. Management of Fusarium head blight of wheat and barley. Crop Protection 73: 100-107.

Weather INnovations Consulting LP, 2018. Decision support models. DONCast. Available at: https://www.weatherinnovations.com/ models.cfm

Whitaker, B.K. and Bakker, M.G., 2019. Bacterial endophyte antagonism toward a fungal pathogen in vitro does not predict protection in live plant tissue. FEMS Microbiology Ecology 95: fiy237.

Wilson, W., Dahl, B. and Nganje, W., 2018. Economic costs of Fusarium head blight, scab and deoxynivalenol. World Mycotoxin Journal 11: 291-302.

Windels, C.E., 2000. Economic and social impact of Fusarium head blight: changing farms and communities in the northern Great Plains. Phytopathology 90: 17-21.

Wu, J., Doan, H. and Cuenca, M.A., 2006. Investigation of gaseous ozone as an anti-fungal fumigant for stored wheat. Journal of Chemical Technology and Biotechnology 81: 1288-1293.

$\mathrm{Xu}, \mathrm{X}$., Nicholson, P. and Ritieni, A., 2007. Effects of fungal interactions among Fusarium head blight pathogens on disease development and mycotoxin accumulation. International Journal of Food Microbiology 119: 67-71.

Xue, S., Li, G., Jia, H., Xu, F., Lin, F., Tang, M., Wang, Y., An, X., Xu, H., Zhang, L., Kong, Z. and Ma, Z., 2010. Fine mapping Fhb4, a major QTL conditioning resistance to Fusarium infection in bread wheat (Triticum aestivum L.). Theoretical and Applied Genetics 121: $147-156$
Xue, A.G., Chen, Y., Voldeng, H.D., Fedak, G., Savard, M.E., Längle, T., Zhang, J. and Harman, G.E., 2014a. Concentration and cultivar effects on efficacy of CLO-1 biofungicide in controlling Fusarium head blight of wheat. Biological Control 73: 2-7.

Xue, A.G., Chen, Y.H., Sant'anna, S.M.R., Voldeng, H.D., Fedak, G., Savard, M.E., Längle, T., Zhang, J.X. and Harman, G.E., 2014b. Efficacy of CLO-1 biofungicide in suppressing perithecial production by Gibberella zeae on crop residues. Canadian Journal of Plant Pathology 36: 161-169.

Yang, M.X., Zhang, H., Kong, X.J., Van der Lee, T., Waalwijk, C., Van Diepeningen, A., Xu, J., Xu, J.S., Cheng, W.Q. and Feng, J., 2018. Host and cropping system shape the Fusarium population: \#-ADONproducers are ubiquitous in wheat whereas NIV-producers are more prevalent in rice. Toxins 10: 115.

Yerkovich, N., Palazzini, J.M., Sulyok, M. and Chulze, S.N., 2017. Trichothecene genotypes, chemotypes and zearalenone production by Fusarium graminearum species complex strains causing Fusarium head blight in Argentina during an epidemic and nonepidemic season. Tropical Plant Pathology 42: 190-196.

Yli-Mattila, T., Gagkaeva, T., Ward, T.J., Aoki, T., Kistler, Corby, H. and O'Donnell, K., 2009. A novel Asian clade within the Fusarium graminearum species complex includes a newly discovered cereal head blight pathogen from the Russian Far East. Mycologia 101: 841-852.

Young, J.C., Zhu, H. and Zhou, T., 2006. Degradation of trichothecene mycotoxins by aqueous ozone. Food and Chemical Toxicology 44: 4.17-424.

Yu, J., Kwon, S.-J., Lee, K.-M., Son, M. and Kim, K.-H., 2009. Complete nucleotide sequence of double-stranded RNA viruses from Fusarium graminearum strain DK3. Archives of Virology 154: 1855-1858.

Yu, J., Lee, K.-M., Son, M. and Kim, K.-H., 2016. Effects of deletion and overexpression of Fusarium graminearum gene FgHal2 on host response to mycovirus Fusarium graminearum virus 1. Molecular Plant Pathology 16: 641-652.

Yu, J., Lee, K.-M., Cho, W.K., Park, J.Y. and Kim, K.-H., 2018. Differential contribution of RNA interferences components in response to distinct Fusarium graminearum virus infections Journal of Virology 92(9): e01756-17.

Yuan, S. and Zhou, M., 2005. A major gene for resistance to carbendazim, in field isolates of Gibberella zeae. Canadian Journal of Plant Pathology 27: 58-63.

Zadoks, J.C., Unh, A., Rice, I. and Board, E., 1974. A decimal code for the growth stages of cereals. Weed Research 14: 415-421.

Zeller, K.A., Bowden, R.L. and Leslie, J.F., 2003. Diversity of epidemic populations of Gibberella zeae from small quadrats in Kansas and North Dakota. Phytopathology 93: 874-880.

Zeller, K.A., Bowden, R.L. and Leslie, J.F., 2004. Population differentiation and recombination in wheat scab populations of Gibberella zeae in the United States. Molecular Ecology 13: 563-571.

Zhang, H. and Wang, B., 2015. Fates of deoxynivalenol and deoxynivalenol-3-glucoside during bread and noodle processing. Food Control 50: 754-757.

Zhang, H., Van der Lee, T., Waalwijk, C., Chen, W., Xu, J., Xu, J., Zhang, Y. and Feng, J., 2012. Population analysis of the Fusarium graminearum species complex from wheat in China show a shift to more aggressive isolates. PLoS ONE 7: e31722. 
Zhang, J.-B., Wang, J.-H., Gong, A.-D., Chen, F.-F., Song, B., Li, X., Li, H.-P., Peng, C.-H. and Liao, Y.-C., 2013. Natural occurrence of Fusarium head blight, mycotoxins and mycotoxin-producing isolates of Fusarium in commercial fields of wheat in Hubei. Plant Pathology 62: 92-102.

Zhao, Y., Selvaraj, J.N., Xing, F., Zhou, L., Wang, Y., Song, H., Tan, X., Sun, L., Sangare, L., Folly, Y.M.E. and Liu, Y., 2014. Antagonistic action of Bacillus subtilis Strain SG6 on Fusarium graminearum. PLoS ONE 9: e92486.
Zheng, Y., Hossen, S., Sago, Y., Yoshida, M. and Nakagawa, H., 2014. Effect of milling on the content of deoxynivalenol, nivalenol, and zearalenone in Japanese wheat. Food Control 40: 193-197.

Zinedine, A., Soriano, J.M., Moltó, J.C. and Mañes, J., 2007. Review on the toxicity, occurrence, metabolism, detoxification, regulations and intake of zearalenone: an oestrogenic mycotoxin. Food and Chemical Toxicology 45: 1-18. 
